\title{
BIOMEDICINES-CINA AGAINST COVID-19: CONTROLLED PLANT DISEASES ENRICHED SCIENCE AND TECHNOLOGY COMMUNICATION GREEN ECONOMY
}

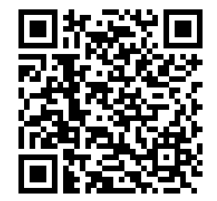

\author{
Subhas Chandra Datta, Ph.D. ${ }^{* 1}$ (iD \\ ${ }^{* 1}$ Headmaster, Secretary and Researcher, Eco-club Research Unit, Kanchannagar D.N. Das High \\ School (HS), Kanchannagar, Burdwan Municipality, Purba Bardhaman, Burdwan-713102, West \\ Bengal, India
}

DOI: https://doi.org/10.29121/granthaalayah.v8.i9.2020.1537

Article Type: Research Article

Article Citation: Subhas Chandra Datta, Ph.D.. (2020). BIOMEDICINES-CINA AGAINST COVID-19: CONTROLLED PLANT DISEASES ENRICHED SCIENCE AND TECHNOLOGY COMMUNICATION GREEN ECONOMY. International Journal of Research GRANTHAALAYAH, 8(9), 234-255. https://doi.org/10.29121/granthaa layah.v8.i9.2020.1537

Received Date: 15 September 2020

Accepted Date: 30 September 2020

Keywords:

Biomedicines-Cina

Controlled-COVID-19-Plant-

Diseases

Enriched

Science-Technology-

Communication-Green-Economy

\section{ABSTRACT}

The economic-plant-mulberry is infected by different pathogens causing diseases and significantly reduces silk production. Though pesticides are the most effective means of control, but they are expensive and not environment friendly. On the other hand, the ongoing spread of the novel coronavirus, forming epidemic, affecting human civilizations, because recently, no appropriate antiviral drugs for effective treatments or vaccines against COVID-19. To meet the challenge, it is reported that the therapeutic value of traditional-, complementary- and alternative-biomedicines-Artemisia nilagirica, has been used for centuries, to overcome various medical disorders. So, to concur with the situation, it will require new and more efficient solutions, technologies, and products. Present pretreatment with ultra-high-diluted biomedicines-Cina, prepared from the flowering meristems of Artemisia nilagirica (Clarke) pamp, mixed with water at an extremely low dose, were applied by foliar spray once daily for 15 days @ 10 $\mathrm{ml} /$ plant, against naturally occurring, root-knot-, leaf spot-, powdery mildew-, mosaic- and tukra- mulberry diseases, in field trials and silkworms rearing. Pretreatment-investigations have revealed that ultra-high-diluted-Cina, highly effective in ameliorating different mulberry-diseases by inducing their natural defense-response against pathogens-infection and leaving no residual-toxicity in the leaves to affect the growth of silkworms also. It can be concluded that the ultrahigh-diluted, eco-friendly easily-available, easily applicable-Cina, at an extremely low dose, not only used as a potential-biomedical-drug against various plantdiseases, by inducing natural-defense- response, but also, it may be effective against COVID-19 for vaccinations and clinical trials by boosting the natural immune system for the improvement of Science and Technology communication cost-effectiveness green-economy and biodiversity conservations as well as bioapplications issues. And the future clinical-scientists develop all aspects of clinicalcase-reports by publishing in the appropriate medical research archives, with the sincere hope that this crisis will soon be over and the whole world, may fight against the COVID-19 war, retaining normal forms of human civilizations globally.

\section{INTRODUCTION}

The mulberry, is a major foreign exchange earner of India, which is short about $30 \%$ to fulfill the home requirements [1], due to the mulberry diseases, caused by pathogens, which affects the silk -yield in terms of quality and quantity [1], [2], [3], [4], [5], [6], [7], [8], [9], [10], [11], [12], [13], [14], [15], [16], [17], [18], [19], [20], [21], [22], [23], [24], [25], [26], [27]. Synthetic and chemical pesticides are the most effective means of control, but they are

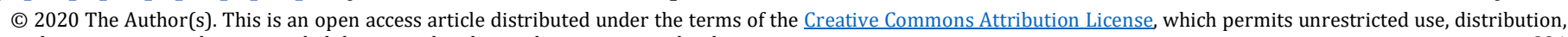
and reproduction in any medium, provided the original author and source are credited. 
both expensive and environmentally unfriendly, toxic to man and not-biodegradable [28], [29]. The use of plant extracts affects our biodiversity conservation [30], [31], [32], [33], [34] and climate change will determine future food security [35]. Cropping pattern [35], [36], and expert comments are applied to achieve sustainable agriculture in the future [35], [36]. Currently novel coronavirus disease- COVID-2019 epidemic problems, identified by the Chinese authorities [37], forming pandemic with profound effects on our private and professional life, the world economy, and the social life and humanity [38] with unusual viral pneumonia [39] and scientists are working with the genome of COVID [40], [41] which could potentially emerge in humans in the future [41]. For this, WHO, responses to the outbreak[37] and warns, for this virus is going to stay among humans for a long time, [41] which has currently no effective treatment [42], [43] due to genetic resistance [44], sufficiently divergent for the future evolution, adaptation, and spread of virus [45]. So, current views on economic impact on India, beyond, and global is going to be steep [46], [47] and it is likely to offers a cure or at least a vaccine [46], [47] due to the pandemic situation is analogous to war and the delay of every week in the deployment of a vaccine to the seven billion humans on earth will cost thousands of lives [48]. Antimalarial drugs widely used against COVID-19 heighten the risk of cardiac arrest. How can doctors minimize the danger? [49].

A number of plant bioagents- or - nematicides [2], [35], [36], intercropping-[50] and crop rotation-, animal bionematicides [34], [51], [52], [53], and biomedicines, only stand as a suitable- and useful- against different plants-, animals- and human- diseases caused by pathogens[2],[4], [8], [10], [17], [20], [21], [24], [51], [52]. But it remains a problem of biodiversity conservation green economy applications and not always cost-effective [34], [51], [53]. Now, the traditional medicine [54], [55], [56], [57], [58] 'Indian wormwood'- Artemisia nilagirica, is considered for centuries against diseases. The clinical biomedicines; Cina, is being used traditionally to overcome more than 50medical complications due to its low toxicity and high efficacy [11], [14], [15], [22], [25], [33], [54], [59] and it is highly effective in ameliorating different plan and animal diseases [5], [7], [11], [12], [14], [15], [22], [25], [59].

The aims and objectives were to investigate new and more efficient solutions, technologies and products for controlling disease, by using an ultra-high diluted biomedicines-Cina with pretreatment, against naturally occurring, root-knot-, leaf spot-, powdery mildew-, mosaic- and tukra- diseases of mulberry, in field trials and silkworms rearing, which influence for the development ideas of vaccines and treatments against coronavirus disease (COVID19) outbreak by using these ultra-high diluted biomedicines-Cina at an extremely low dose, which may resist the COVID-19 by boosting our immune system.

\section{MATERIALS AND METHODS}

\subsection{PREPARATION OF BIOMEDICINES-CINA MOTHER TINCTURE (MT)}

Air-dried and powdered flowering meristems of A. nilagirica, (Plate 1), were extracted with 90\% ethanol and the crude residues were dissolved in $90 \%$ ethanol at $1 \mathrm{mg} / \mathrm{ml}$ concentration and were formed homeopathic mother tincture of A. nilagirica called Cina MT (Original Solution or Crude Extract i.e. Mother Tincture) [5], [7], [11], [16], [18], [22], [25], [33], [60].

\subsection{PREPARATION OF HIGH DILUTED LIQUID BIOMEDICINES-CINA 30C AND -CINA 200C MEDICINE}

The crude extract of $A$. nilagirica, named Cina MT were diluted with $90 \%$ ethanol (1:100) proportionate in a round vial which was filled up to two-thirds of its space, tightly corked and then were given 10 powerful downward strokes of the arm, forming the 1st centesimal potency named Cina1C and all the subsequent potencies were prepared in this way; -Cina 30C and -Cina 200C medicine were prepared respectively [5], [7], [11], [16], [18], [22], [25], [33], [60].

\subsection{PREPARATION OF MEDICATED BIOMEDICINES-CINA 30C AND -CINA 200C GLOBULES}

By the few drops of a liquid potency of; -Cina 30C and -Cina 200C, were prepared respectively [5], [7], [11], [16], [18], [22], [25], [33], [60]. 


\subsection{PREPARATION OF MEDICATED CONTROL GLOBULES}

Cina 30C and -Cina 200C, [5], [7], [11], [16], [18], [22], [25], [33], [60] by the same way.

\subsection{PREPARATION OF ULTRA HIGH DILUTED BIOMEDICINES-CINA30C AND-CINA 200C PRETREATMENT TEST- AND CONTROL- SOLUTIONS}

By mixing with sterile distilled water in the proportion of $7.2 \mathrm{mg}$ globules/ml of water respectively [5], [7], [11], [16], [18], [22], [25], [33], [60].

\subsection{MORTALITY TEST}

For the assessment of the direct effect of; -Cina 30C and -Cina 200C pretreatment - test solution [5], [7], [11], [16], [18], [22], [25], [33], [60].

\subsection{SITE OF THE PRETREATMENT EXPERIMENTAL PLOTS}

The field experiment was carried out at the Sriniketan Sericultural Composite Unit, India where throughout the year, the whole mulberry field was naturally infected with root-knot disease of mulberry plants (Morus alba L., cv. S1) caused by Meloidogyne incognita (Kofoid \& White) Chitwood, root-knot nematodes pathogens and every year in September-October occurrence of four foliar diseases were seen and these were: leaf spot disease caused by Cercosporam moricola (Cooke) fungus pathogens, powdery mildew disease caused by Phyllactinia corylea (Pers.) Karst fungus pathogens, mosaic disease caused by mosaic virus pathogens, and tukra disease caused by Maconellicoccus hirsutus (Green) mealybug pathogens [2], [4], [7], [8], [10], [18], [20], [22], [24], [27].

\subsection{ESTIMATION OF THE NEMATODE PATHOGEN POPULATION}

Soil and root samples [28], [29], [31], [59], [60], [61], [62] were taken at random to determine the extent and intensity of M. incognita -pathogen infestation [2], [4], [7], [8], [10], [18], [20], [22], [24], [27].

\subsection{PREPARATION OF FIELDS}

The first soil, was mixed with the yard manure (2:1 vol/vol), and were assessed the M. incognita population [2], [4], [7], [8], [10], [18], [20], [22], [24], [27] and this naturally infected soil-filled area, demarking the pretreated field, replicated thrice [2], [3], [6], [7], [8], [9], [10], [11], [12], [13], [14], [15], [16], [17], [18], [20], [25], [53].

\subsection{PLANTATION OF MULBERRY CUTTING}

Mature three years old mulberry cutting, Morus alba L., cv. S, were planted and allowed to grow for a period of three months [2], [3], [4], [7], [8], [10], [11], [12], [13], [14], [15], [16], [17], [18], [20], [21], [22], [24], [25], [26], [27].

\subsection{DIVISION OF GROUPS AND PLOTS}

After three months of growth of mulberry, the M. incognita population was estimated in the soil as well as roots [28], [29], [31], [59], [60] and the plants were allowed to grow for a period of 137, replicated three times [2], [3], [6], [7], [8], [9], [10], [11], [12], [13], [14], [15], [16], [17], [18], [20], [25], [53]. 


\subsection{PRETREATMENT WITH HIGH DILUTED BIOMEDICINES-CINA30C AND -CINA200C -TEST AND - CONTROL SOLUTIONS}

Seventy-six days after pruning, of mulberry plants, all the pretreatment was done by foliar spray @10 ml/plant $(7.2 \mathrm{mg} / \mathrm{ml}$ concentration) once daily for 15 days with -Cina 30C and -Cina 200C -test solutions and -control solution respectively [5], [7], [11], [12], [13], [14], [15], [16], [18], [22], [25], [33], [60]. At fifteen days after the last pretreatment, all the parameters of diseases were assessed again for each group [5], [7], [11], [12], [13], [14], [15], [16], [18], [22], [25], [33], [60] and all the data were used for statistical analysis by Student's t-test [2], [3], [6], [7], [8], [9], [10], [11], [12], [13], [14], [15], [16], [17], [18], [20], [21], [22], [23], [24], [25], [53].

\subsection{ANALYSIS OF RESIDUE}

The residues run in a thin layer chromatography plate (TLC) with the standard; - Cina 30C and Cina 200C, pretreatment test substances respectively [5], [7], [11], [12], [13], [14], [15], [16], [18], [22], [25], [33], [60].

\subsection{PLANT PATHOGENS CAUSED MULBERRY DISEASES}

Root-knot Disease were assessed by the; total number and surface area of leaves and root-galls / plant [2], [3], [6], [7], [8], [9], [10], [11], [12], [13], [14], [15], [16], [17], [18], [20], [21], [22], [23], [24], [25], [53]. The total protein content of the leaf and root were determined [31], [32]. All the data from experiments were counted for statistical analysis by the student's t-test [2], [3], [6], [7], [8], [9], [10], [11], [12], [13], [14], [15], [16], [17], [18], [20], [21], [22], [23], [24], [25], [53]. Every year in September-October occurring, the different foliar diseases, observed in the sericulture field, were: leaf spot disease, tukra disease (Plate 3), powdery mildew disease (Plate 4) and mosaic disease (Plate 5). All the diseases identified according to their characteristic symptoms by the experts concerned [26], [27], [30].

\subsection{REARING OF SILKWORMS}

The eggs of a mother moth of the multivoltine 'Nistari' race (Bombyx mori L.), after hatching and brushing 1st stage silkworm larvae in the rearing tray [1],[2], [3], [4], [7], [8], [9], [10], [11], [12], [13], [14], [15], [16], [17], [18], [20], [21], [22], [23], [24], [26], [27], [63], [64], [65]. Mulberry leaves were used for feeding fifteen days after the last pretreatment with biomedicines; Cina 30C and Cina 200C, respectively. The fresh silk gland weight of mature 5th instars larvae (Plate 6) (before start spinning), starting time to spinning (Plate 7), span of spinning, fresh cocoon weight, fresh shell weight, silk layer ratio (SR \% = Shell weight / Cocoon weight X 100), effective rate of rearing (ERR $\%=$ Number of cocoon harvested / Number of silkworms hatched X 100), sex ratio percentage (Number of male adults emerged / Number of female adults emerged X 100) and egg-laying capacity of mother moth were determined [1],[2], [3], [4], [7], [8], [9], [10], [11], [12], [13], [14], [15], [16], [17], [18], [20], [21], [22], [23], [24], [26], [27], [63], [64], [65]. All the data from the rearing trial were used for statistical analysis by the student's t-test.

\subsection{SCIENCE AND TECHNOLOGY COMMUNICATION GREEN-ECONOMY APPLICATIONS}

The activity and the importance of "Pretreatment with Ultra High Diluted biomedicines; Cina 30C and Cina 200C, at an Extremely Low Doses, Use as Potential Cost-Effective Biomedicines Against Various Pathogens including COVID-19: Enriching Science and Technology Communication Green-economy Applications and Healthcare-, Defense response- and Immunity- as well as Biodiversity Conservation- Issues" in different audiovisual media (TV channels), social media, web pages, newspapers, and journals are recorded, which is a platform to promote and discuss different new issues and developments by publishing [1],[2], [3], [4], [7], [8], [9], [10], [11], [12], [13], [14], [15], [16], [17], [18], [20], [21], [22], [23], [24], [26], [27], [63], [64], [65], [66], [67]. 


\subsection{FUTURE IDEAS OR SUGGESTIONS IN RESEARCH}

It will be achieved from typical analysis or justifications of literature review, reports of clinical research trials, or fields note. Then new ideas or hypotheses or suggestions will arise and clearly label them as such trials for education and prevention are the ultimate keys to extending good health globally [1], [2], [3], [4], [7], [8], [9], [10], [11], [12], [13], [14], [15], [16], [17], [18], [20], [21], [22], [23], [24], [26], [27], [63], [64], [65], [66], [67].

\section{RESULTS}

\subsection{TOXICITY TEST ON MORTALITY}

The biomedicines; Cina 30C and Cina 200C, at extremely low doses, had no direct toxic effects on nematodes mortality respectively.

\subsection{ANALYSIS OF RESIDUES TOXICITY}

Mulberry leaves collected fifteen days after the last pretreatment, did not contain any toxic residue of the ultrahigh diluted biomedicines; Cina 30C and Cina 200C.

\subsection{ROOT-KNOT DISEASE}

Table1 shows the pretreatment effects of ultra-high diluted biomedicines; Cina 30C and Cina 200C, at an extremely low doses, on M. incognita pathogens infected mulberry plants in a field trial replicated thrice $(\mathrm{P}<0.01$ by ' $\mathrm{t}$ '- test).

\subsection{FOLIAR DISEASES}

Table 2 shows the pretreatment effects of the ultra-high diluted biomedicines; Cina 30C and Cina 200C, at an extremely low doses, on leaf spot, powdery mildew, mosaic viral and tukra diseases of mulberry plants in a field trial replicated thrice assessed initially (Day- 0) and after a period of 30 days (Day -30) by ' $\mathrm{t}$ '- test $(\mathrm{P}<0.01)$. Both; Cina 30C and Cina 200C, with pretreatment significantly reduced the number of leaves infected with leaf spot, powdery mildew, mosaic viral, and tukra (Plate 3) as compared to the untreated condition (Day- 0). The percentage of control achieved in both drugs respectively; were $60.12 \%$ - and $62.08 \%$ - for leaf spot, $76.88 \%$ - and $77.89 \%$ - for powdery mildew (Plate 4), 64.15\%- and 64.91\%- for mosaic virus (Plate 5), 36.32\%- and 38.42\%- for tukra infection as compared to the untreated level (Day- 0). In the case of infected untreated plots leaf spot, powdery mildew, mosaic viral and tukra diseases showed naturally $27.80 \%, 17.76 \%, 29.37 \%$, and $21.20 \%$ reduction respectively, in 30 days (Day -30).

\subsection{EFFECTS ON FEEDING SILKWORMS}

Table 3 shows the pretreatment effects of the ultra-high diluted biomedicines; Cina 30C and Cina 200C, at an extremely low doses, on diseased infected mulberry plants in a silkworm rearing and field trial replicated thrice on the feeding, growth, and mortality of silkworms $(\mathrm{P}<0.01$ by ' $\mathrm{t}$ '-test). The average consumption of leaves by the 5 th instars (Plate 6), the average number of feeding to cocoon formation (Plate 7), the average number of feeding day to cocoon formation, the average number of escaping- feeding during molting and average molting span days were less for the both; Cina 30C and Cina 200C, -pretreated plants than for infected-untreated (control) ones. 


\subsection{EFFECTS ON SILK PRODUCTION AND REARING PRACTICES}

Table 4 shows the effects of feeding the ultra-high diluted biomedicines; Cina 30C and Cina 200C, at an extremely low dose, -pretreated mulberry leaves on silk production, spinning characters, and rearing practices in a silkworm rearing (Plate 7$)$ and field trial replicated thrice $(\mathrm{P}<0.01$ by ' $\mathrm{t}$ '-test).

\subsection{FUTURE SUGGESTIONS IN RESEARCH}

Here, the results fulfill the goal of a research idea because the present pretreatments with the ultra-high diluted biomedicines; Cina 30C and Cina 200C, at an extremely low dose, need to justify future research.

\subsection{SCIENCE AND TECHNOLOGY COMMUNICATION GREEN ECONOMY APPLICATIONS}

Achieved by; campaign, aware, discuss, arrange workshops and seminars, make news, and publish as abstract regarding the importance of "Pretreatment with the ultra-high diluted; Cina 30C and Cina 200C, at an extremely low doses".

\section{DISCUSSION}

\subsection{ON PRESENT STUDY}

\subsection{ON PLANT DISEASES}

The ultra-high diluted biomedicines; Cina 30C and Cina 200C, at an extremely low doses, ones again not only reduced root-knot, leaf spot, powdery mildew, viral, and tukra diseases but also improved the nutritive value (especially protein) of the pretreated leaves of the naturally infected plants [5], [6], [7], [8], [9], [10], [11], [12], [13], [14], [15], [16], [17], [18], [25].

\subsection{ON SILK PRODUCTION}

Both, biomedicines; Cina 30C and Cina 200C, -pretreatments directly influences on the consumption of leaves, number of feeding, and number of feeding day to cocoon formation, and indirectly effects on molting stage in the infected treated groups from this trial. And due to the ill development of infected untreated (control) batches, silkworm larvae took more time to molt which is proved from the number of escaping feeding during molting. Higher nutritive value especially protein of treated plants contributed to higher growth of silkworm larvae, silk gland weight, cocoon weight, and shell weight which increase silk production significantly for commercial purposes [5], [6], [7], [8], [9], [10], [11], [12], [13], [14], [15], [16], [17], [18], [25].

\subsection{ON GREEN ECONOMY}

The improved health of the larvae, cocoon weight, silk gland, and shell weight from both the biomedicines; Cina 30C and Cina $200 \mathrm{C}$,-pretreated groups of infected plants might have resulted in the fewer starting time to spinning and span of spinning day and the total elimination of the mortality rate respectively. Or, both the biomedicines; Cina 30C and Cina $200 \mathrm{C}$,- might have infused into mulberry leaves a substance that has conferred disease resistance on growing silkworm larvae by releasing defense-related natural products by plants [2], [3], [4], [5], [6], [7], [8], [9], [10], [11], [12], [13], [14], [15], [16], [17], [18], [20], [21], [22], [23], [24], [24], [25], [28], [34], [51], [52], [59], [68], [69]. For this, the effective rate of rearing (ERR\%) is very high in all; Cina 30C and Cina 200C, -pretreated-treatmentbatches which enriches the sericulture industry in many ways, especially for commercial purposes as well as green economy. 


\subsection{ON TOXICITY}

The present study clearly showed that the ultra-highly diluted drugs; Cina 30C and Cina 200C, were pretreated as effective or potential biomedicine at extremely low doses and it had no direct toxic effect on plants but to the pathogens of mulberry plants larvae [2], [3], [4], [5], [6], [7], [8], [9], [10], [11], [12], [13], [14], [15], [16], [17], [18], [20], [21], [22], [23], [24], [24], [25], [28], [34], [51], [52], [59], [68], [69].

\subsection{ON SYNTHESIS}

Both the Cina 30C and Cina 200C could induce synthesis of some antagonistic substances in the pretreated plants. Lectins accumulated in gall regions of root of Hibiscus esculentus infected with M. incognita [2], [3], [4], [5], [6], [7], [8], [9], [10], [11], [12], [13], [14], [15], [16], [17], [18], [20], [21], [22], [23], [24], [24], [25], [28], [34], [51], [52], [59], [68], [69], [70].

\subsection{ON DISEASE RESISTANCE MECHANISMS}

Systemic acquired resistance can be induced by in different crop plants by localized virus infection, nonpathogenic and pathogenic microorganisms, or their culture filtrates or by salicylic acid [2], [3], [4], [5], [6], [7], [8], [9], [10], [11], [12], [13], [14], [15], [16], [17], [18], [20], [21], [22], [23], [24], [24], [25] [28], [34], [51], [52], [59], [68], [69], [70], [71], [72], [73] or by the polar vesicl74 or by the defense-related triterpene glycoside avenaacin A-1 is synthesized [75].

\subsection{ON DEFENSE RESPONSE}

It is reported that a plant plasma membrane ATP binding cassette-type transporter is involved in antifungal terpenoid, for this transporter in disease resistance76-77 or by the share of common antigens with its host plants77 or by the pure compounds of acaciasides [2], [3], [4], [8], [13], [14], [15], [16], [17], [18], [20], [21], [22], [24], [25], [34], [52], [78], [81].

\subsection{ON PATHOGENESIS RELATED PROTEINS}

The ultra-highly diluted drugs; Cina 30C and Cina 200C, may synthesis various antigens particularly (low molecular weight proteins; $5 \mathrm{kd}$ to $25 \mathrm{kd}$ ) and induce defense responses involving several pathogenesis-related proteins in which the naturally infected plant pathogens fail to tolerate [2], [3], [4], [5], [6], [7], [8], [9], [10], [11], [12], [13], [14], [15], [16], [17], [18], [20], [21], [22], [23], [24], [25], [28], [34], [51], [52], [59], [68], [69], like the NE (nematode extract) [3], [82], [83].

\subsection{ON BIODIVERSITY}

Those showed that nematode pathogens infestation somehow serves as a repressor for the expression of defense gene in plant [2], [3], [7], [8], [9], [10], [11], [12], [13], [14], [15], [16], [17], [18], [20], [21], [22], [24], [25], [34], [51], [52], [82], which can be assumed with pretreated-biomedical drugs; Cina 30C and Cina 200C, at an extremely low dose, serve as a stimulus for the expression of many new induced defense-related PR-proteins by systemic acquired resistance.

\subsection{NOW THE KEY QUESTION}

Is, whether plant-derived natural products, the ultra-highly-diluted pretreated-drugs; Cina 30C and Cina 200C, at an extremely low dose, can be used as potential biomedical by inducing defense-response against various plantpathogens causing major mulberry-diseases in a field trial and silkworms rearing [2], [3], [7], [8], [9], [10], [11], [12], [13], [14], [15], [16], [17], [18], '[20], [21], [22], [24], [25], [34], [51], [52], [82], [83]. 


\subsection{NOW THE KEY ANSWER}

Is, the ultra-high-diluted-pretreated-biomedicines; Cina 30C and Cina 200C, at an extremely low dose, was not only highly effective in ameliorating different mulberry diseases but also enriched sericulture industry as well as green agriculture economy. And it is also noted that pretreatment with, the biomedicines; Cina MT and Cina 30C and Cina 200C, at an extremely low dose, and A. nilagirica- extracts or A. auriculifirmis-extracts, at an extremely low dose, show more or less same results [5], [7], [11], [12], [14], [15], [22], [25].

\subsection{FOR FUTURE RESEARCH}

\subsection{IN GENOME BIOLOGY}

We're not completely human, at least when it comes to the genetic material inside our cells; 145-genes from bacteria, other unicellular organisms, and viruses with 17- as possible horizontal gene transfers [84], the genomic sequencing $96.2 \%$ identical to a bat coronavirus and shares a 79.5\% sequence identity to SARS-CoV [84], [85], [86], deal with the structure and function of genetic material underpinning all organisms [85], [86], [87], [88]. Approximately, ten percent of the human genome is made of bits of virus- DNA [89]. Human endogenous retroviruses are by far the most common virus-derived sequences in the human genome 90 which don't always require a body [91].

\subsection{IN GENETIC RESISTANCE}

It is reported that genetic resistance to coronavirus infection according to those three host resistance mechanisms: genetic control [44] and SARS-CoV-2 is the etiological agent responsible for the pandemic COVID-19 outbreak and the main protease (Mpro) of SARS-CoV-2 is a key enzyme that plays an important role in helping in viral replication and transcription-structure-based design of antiviral drug candidates targeting the SARS-CoV-2 main protease [92].

\subsection{IN IMMUNE SYSTEM BLUEPRINT}

Once the virus infects the host cell, it takes over the host cell's machinery to produce more viruses. The host cell essentially becomes a virus factory. When the human body is attacked by germs, the immune system kicks into gear to fight, by improving the immune system, creates a blueprint of the attacking agent, by which, the body effectively remembers the germ - enabling a person to fight for re-infection by the same or similar viruses [93].

\subsection{TRADITIONAL MEDICINE IN HUMAN HISTORY}

In the evolution of human history shows the people are using traditional medicine for therapeutic purposes, and the $70 \%-80 \%$ population is primarily dependent on animals and plant-based [37], [46].

\subsection{THERAPEUTIC VALUE OF TRADITIONAL MEDICINES}

It is reported that the 'Indian wormwood'- Artemisia nilagirica, is considered against many ailments as it is possessed to have high content of biologically active molecules and essential oils. It has been used since centuries in antimicrobial, antifungal, antibacterial, and filarial, insecticidal, antiulcer, anticancer, antioxidant, anti-proliferative, healing potential, neurological disorders, tuberous sclerosis, dermal infection, larvicidal, anti-inflammatory activities, anti-asthmatic and anti-malarial activity, Parkinson's disease, Alzheimer's disease, hypertension, diabetes, atherosclerosis, cardiovascular diseases, cytotoxic, malignancy, genetic abnormalities, diabetes, epilepsy, asthma, sychoneurosis, depression, anxiety and stress, leucorrhoea, threatened abortion, hemoptysis, tuberous sclerosis, skin diseases, immunological disorders, and the aging process, and the pharmacological studies confirm its therapeutic value due to the presences of the wide range of chemical compounds which indicate that the plant could 
serve as a potent material for the development of novel agents having good efficacy in various disorders in the coming years [54], [55]. It is used for the treatment of human parasites, animals, and plants. The common photochemical of $A$. nilagirica that causes effective results on human health care biologically active chemical compounds are flavonoids, alkaloids, tannins, glycosides, phenol, saponins, terpenes, amino acids, quinines, phlobatannins and volatile oils, polysaccharides, sesquiterpene lactones, coumarins and acetylenes, and terpenoids [54], [55], [56], [57], [58]. Forty-three constituents (98.16\% essential oil); 79.91\% monoterpenoids and $18.25 \%$ sesquiterpenoids, $\alpha$-Thujone (36.35\%), $\beta$-thujone $(9.37 \%)$, germacrene $D(6.32 \%)$, 4-terpineol $(6.31 \%), \beta$ caryophyllene $(5.43 \%)$, camphene $(5.47 \%)$ and borneol $(4.12 \%)$, were the major constituents from aerial parts of Artemisia nilagirica [94]. The Artemisia has a diverse range of activities for medicinal uses in human and plant diseases ailments due to possess several active constituents that work through several modes of action and the 1,8cineole, beta-pinene, thujone, artemisia ketone, camphor, caryophyllene, camphene and germacrene $\mathrm{D}$ are the major components in most of the essential oils of this plant species [95]. Artemisia has long been not only used in traditional medicine and but also as a food source for different functions in eastern Asia [96]. Its essential oils has hepatoprotective- and hepatic non-toxic- effects, and as a natural source of hepatoprotective agent96. But, 4th May 2020, WHO recognizes that Artemisia annua are being considered as possible treatments for COVID-19 and should be tested for efficacy and adverse side effects? [97].

\subsection{THERAPEUTIC APPROACH}

Recently, the NovavaxInc, which contributed to the development of other epidemic vaccines, has announced it is currently in pre-clinical animal trials for several multiple nanoparticle COVID-19 vaccine candidates, by using their recombinant protein, the adjuvant is 'saponin-based' and it has shown a "potent and well-tolerated effect" [98], [99]. Scientists are trying to discover novel inhibitor molecules against enzymes Mproand ACE2 by the use of phytochemicals, which be utilized for further innovation and development of antiviral compounds against Coronavirus [100].

\subsection{VACCINATION}

So, for successful vaccination requires four components. Human Immunomics Initiative (HII) aims to decode the underlying mechanisms and rules of how the human immune system fights disease with advances in computing and artificial intelligence, genomics, systems biology, and bioinformatics101. And should follow the guideline of WHO entitled "Vaccine-preventable diseases and vaccines" [37], [101], [102]. It reduces wait time for emergency vaccination [105] and one or more randomized trials will be needed to answer ${ }^{106}$. Then, with allopath is using trial and error method in some cases to treat COVID-19 [97], [107] and according to the World Health Organization's latest table of COVID-19 vaccines, 124-candidates with technologies or platforms. Merck's new investments focus on two different COVID-19 vaccines that are already in early clinical trials [108].

\subsection{DEVELOPMENT OF IDEAS FOR EMERGENCY VACCINATION}

In this situation, it will be essential to inform public health expertise for moving academic research forward during COVID-19, and a gradual, stepwise approach to reopening [109]. And, the present results and discussion fulfill the goal for the research suggestions because the present pretreatments with the ultra-high diluted biomedicines; Cina MT or - Cina 30C and Cina 200C- liquid or - Cina 30C and Cina 200C- globules, at an extremely low doses, prepared from the flowering meristem of $A$. nilagirica, mixed with water at an extremely low dose, need to justify future research [5], [7], [11], [12], [14], [15], [16], [18], [22], [25], [33], [60], [97].

\subsection{IDEAS FOR EMERGENCY VACCINATION}

Perhaps no country is more vulnerable to COVID-19's depredations than Yemen which was grappling with "the largest humanitarian crisis in the world ${ }^{110}$. So, we urgently need effective drugs for coronavirus disease 2019 (Covid19), but what is the quickest way to find them ${ }^{111}$ ? For this, apply the plasma from COVID-19 survivors to help save others [112]. Recently, the Max Planck Institute test Artemisia annua plant extract [97], [113] against the novel 
coronavirus disease (COVID-19 and A. annua extracts show very little toxicity and artemisinin-based drugs are widely used to treat malaria even in newborns [113]. So, I think, though it is maybe applicable as a vaccine, but it will not be cost-effective and affects biodiversity in conservation with green economy applications [5], [7], [11], [12], [14], [15], [16], [18], [22], [25], [33], [60], [114]. Hence, biomedicines, Cina MT [97], [113] may be used in vaccine formulations to regulate immune function by acting as -antioxidants and -scavenge oxidative stress ${ }^{5,7,11-}$ $16,18,22,25,33,6097,113$ due to the presence of chief constituents of many human health care potential biologically active chemical compounds. that work through several modes of action; are flavonoids, alkaloids, tannins, glycosides, phenol, saponins, terpenes, amino acids, quinines, phlorotannins, polysaccharides, sesquiterpene lactones, coumarins, acetylenes, and volatile oils; terpenoids, monoterpenoids, sesquiterpenoids, $\alpha$-Thujone, $\beta$-thujone, betapinene, germacrene D, 4-terpineol, $\beta$-caryophyllene, 1, 8-cineole, artemisia ketone, camphor, caryophyllene, camphene, and borneol etc., - isolated from the crude extract of A. nilagirica flowering meristem [54], [55], [56], [57], [58], [94], [95], [96], [97].

\subsection{IDEA-I:}

So, the adjuvant Cina MT [97], [113] may be used with recombinant protein nanoparticle antigens derived from the coronavirus spike protein and combine these antigens with its adjuvant Cina MT for the final formulation of the vaccine and it may be shown a "potent and well-tolerated effect" through stimulating the entry of antigen-presenting cells into the injection site and enhancing antigen presentation in local lymph nodes, boosting immune responses [5], [7], [11], [12], [14], [15], [16], [18], [22], [25], [33], [60], [98], [99], [114]. In a letter as an e-mail, the Science Advisory Board Net, at Express Cells, for their business of creating better knock-in cell lines for drug discovery, toxicology, and other biologic research and add for purchase SARS-CoV-2 Spike Protein [115] and the readily available coronavirus spike proteins may be helped to use for vaccine preparation which may fight against "COVID Toes among kids [116], which gain immunity before the onset of disease or disease symptoms in an individual as a prevention rather than cure [117] and in a clinical study shows the efficiency of triple antibiotic mixture process in immature apex [117], [118]. It is obligatory that information on ClinicalTrials.gov, a resource provided by the U.S. National Library of Medicine (NLM), to the National Institutes of Health (NIH) or other agencies of the U.S. Federal Government, is provided by study sponsors and investigators, and they are responsible for ensuring that the studies follow all applicable laws and regulations [116], [117], [118], [119], [120], [121]. It is also studied the costeffectiveness of emergency care interventions in low and middle-income countries like India [117], [118], [119], [120]. But it will not also be; -cost-effective and not easily -prepare able, -available and -not help in green economy applications [5], [7], [11], [12], [14], [15], [16], [18], [22], [25], [33], [60], [97], [113].

\subsection{IDEA-II}

The adjuvant biomedicines, Cina MT97,113 may be used with anti-Human antibodies like IgG (A80-104A, A80105A), IgM (A80-100A, A80-101A), \& IgA (A80-102A, A80-103A) and offer treatments or vaccine preparation of COVID-19 (SARS-CoV-2) and it may also be accelerated the discovery to improve lives [101], [116], [117], [118], [119], [120], [121], [122]. After getting successful clinical trials, the concerned authorities, may be permitted for the use as a vaccine for treatments [101], [116], [117], [118], [119], [120], [121]. But it will not also be; -cost-effective and not easily -prepare able, -available and -not help in green economy applications [5], [7], [11], [12], [14], [15], [16], [18], [22], [25], [33], [60].

\subsection{IDEA-III OR IDEA-IV}

The ultra-high diluted biomedicines; -Cina 30C liquid OR -Cina 200C liquid, @ 10 drops mixed with 10 ml of sterile distilled- or pure drinking -water, maybe orally administered once daily (before taking any food) for 15 days, against naturally occurring virus infections15-days before symptom onset OR illness onset (as a vaccine) OR onset of symptoms where patients in hospital-associated COVID-19 infections has been reported (treatments) [123], [124]. In the case of treatment, depending on the disease intensity, the dose may be increased 3-4 times a day. It is moderately cost-effective and easily -prepare able and -available drug [117], [118], [119], [120]. After getting 
permission from the concerned authorities, the Cina 30C OR -Cina 200C -liquid, may be directly used for "Clinical trial or as a Vaccine" because ultra-high diluted biomedicine -Cina 30C OR -Cina 200C -liquid, have actually no drug molecules (due to cross the Avogadro number i.e., 6.023 X 1023) [101], [116], [117], [118], [119], [124], [125]. It is well known that Avogadro limit washed out by nano-associates of water which continue as information carriers in serial dilutions and end up with the generalized concept of medicines and these structures, in their turn, influence near-matching bio-molecules to serve as medicines, like antibiotics, leading to a generalized concept of medicine [120], [121]. It may be more; cost-effective [117], [118], [119], [120], easily prepare able, easily available, easily applicable and help in green economy applications also [5], [7], [11], [12], [14], [15], [16], [18], [22], [25], [33], [60], [97], [113].

\subsection{IDEA-V OR IDEA-VI}

The ultra-high diluted biomedicine globules; -Cina 30C OR -Cina 200C, @ 10- medicated- globules (7.2mg), maybe orally administered once daily for 15 days, against naturally occurring virus infections 15 -days before symptom onset OR illness onset (as a vaccine) OR onset of symptoms where patients admitted in hospital with COVID-19 infections has been reported (treatments) [120]. In the case of treatment, depending on the disease intensity, the dose may also be increased 3-4 times a day. It is the most cost-effective and easy -prepare able and available drug [117]. The biomedicine globules; -Cina 30C OR -Cina 200C, may also be directly used for "Clinical trial or as a Vaccine" after getting permission from the; -WHO, -ClinicalTrials.gov., -U.S. NLM and -NIH [101], [116], [117], [118], [119], [124], [125]. It is the most; cost-effective, easily prepare able, easily available, and help in biodiversity conservations and green economy applications issues [5], [7], [11], [12], [14], [15], [16], [18], [22], [25], [33], [60] and easily applicable also [97], [113].

Recently, scientists in Israel, Netherlands claim progress in COVID-19 monoclonal antibody- 47D11 trials [126] and Italy claims to develop first COVID-19 vaccine ${ }^{127}$. India applied the very old theory for vaccine preparations and plasma therapy is being treated as yet another complementary treatment to help the COVID-19 patients recover [127]. The current pandemic locust attack in India causes the crises of food securities [128], the world has joined hands to find a vaccine for the novel coronavirus. At present, many groups (80) are working globally for vaccines for humans which normally takes years to develop. Currently, there are ${ }^{111}$ potential vaccines for the SARS-CoV-2 which are in different stages of clinical trials [127].

While a cure or vaccine for COVID-19 is not available, in the absence of any side-effects and adverse interactions with any conventional medicines along with a robust safety profile and repeated evidence-based successes against viral infections, the ultra-high diluted biomedicine; -Cina MT or -Cina 30C liquid or -Cina 30C globules, at an extremely low dose, may play an important role in the fight against COVID-19123. It is the most; cost-effective, easily prepare able, easily available, and help in biodiversity conservations and green economy applications issues also [5], [7], [11], [12], [14], [15], [16], [18], [22], [25], [33], [60] and should be applicable for clinical trials as early as possible [97], [113].

Now it is planned to publish six-ideas for current outcomes and therapies on coronavirus disease (COVID-19) outbreak that helps the readers as well as a scientific community to take measures or treatment opportunities or discovery of vaccines to avoid new coronavirus.

\section{Conclusions}

It can be concluded that the plant-derived natural products, ultra-high-diluted cost-effective, easily applicable, pretreated-ecofriendly easily available drugs; Cina, at an extremely low dose, used as a potential biomedical drug by inducing defense- response against various pathogens causing major mulberry diseases and the "Six Ideas; for vaccine and clinical trials with the ultra-high diluted biomedicines; Cina MT OR Cina 30C liquid OR Cina 200C liquid OR Cina 30C globules OR Cina 200C globules, at an extremely low dose, against COVID-19 by boosting the immune system for the Improvement of Science and Technology Communication Green Economy Applications Issues" and the future clinical-scientists develop all aspects of clinical-case-reports globally with the sincere hope that this crisis will soon be over and the whole world may retain in normal forms by fighting against COVID-19 war. 

Economy

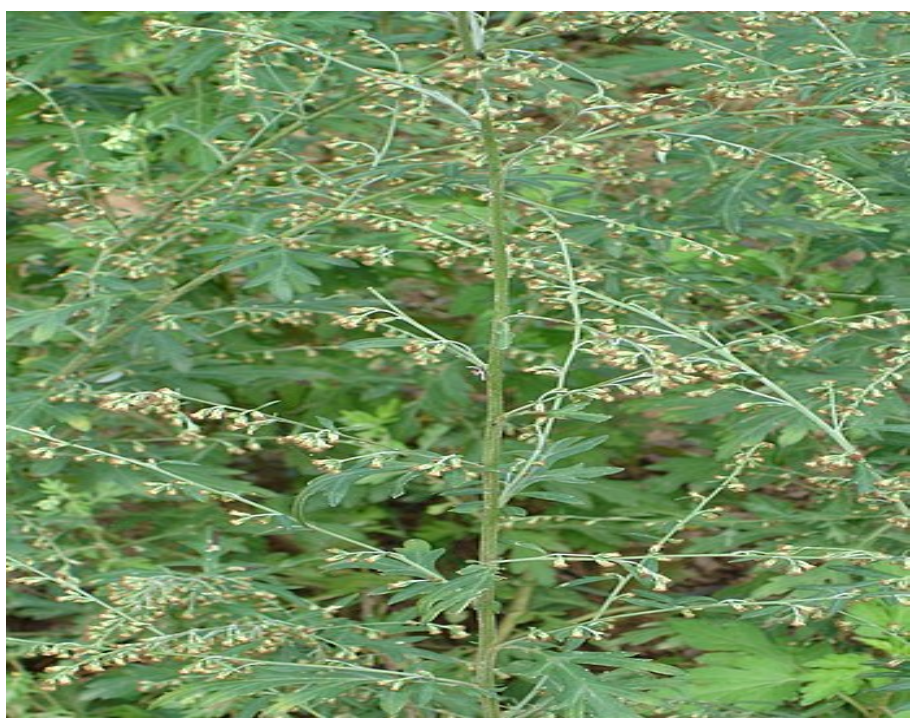

Plate 1: Flowering meristem of Artemisia nilagirica (Clarke) pamp

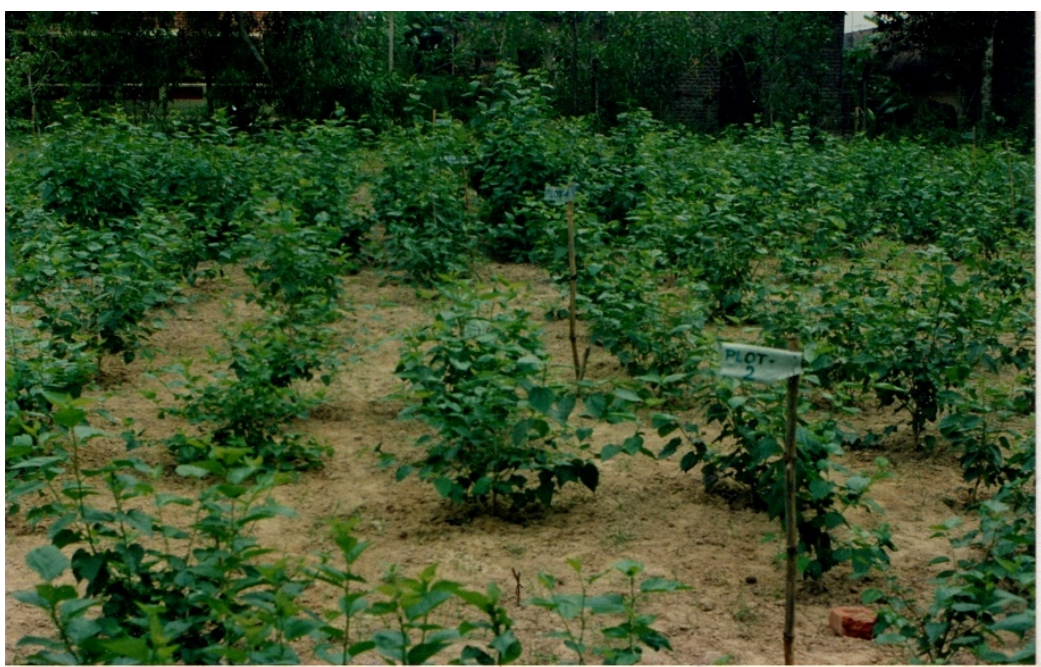

Plate- 2. Field grown with mulberry plants naturally infected with $M$. incognita

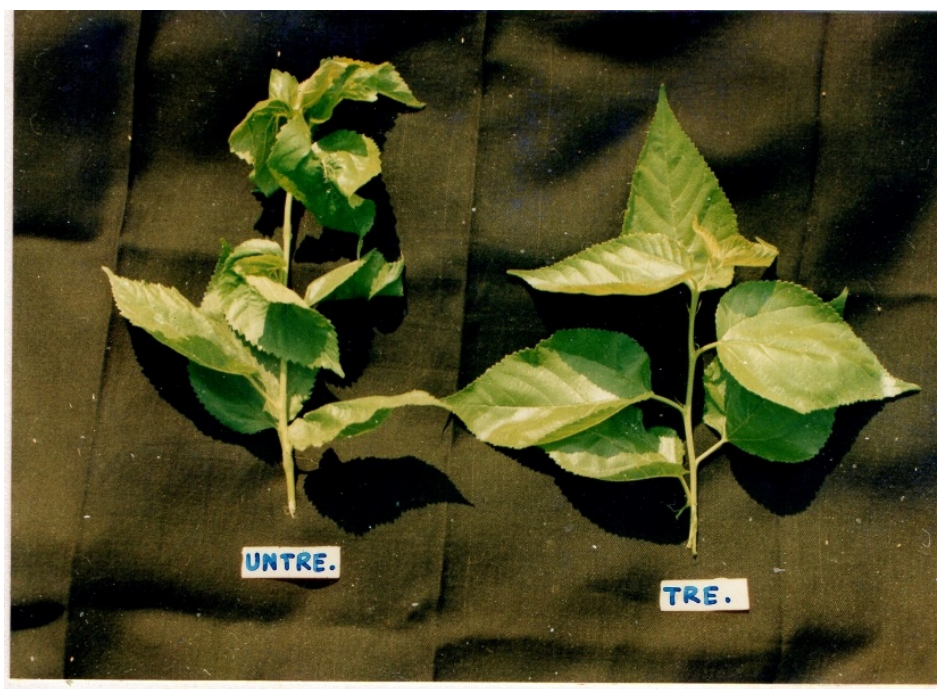

Plate- 3. Mulberry leaf infected with 'Tukra disease' 
Subhas Chandra Datta, Ph.D.

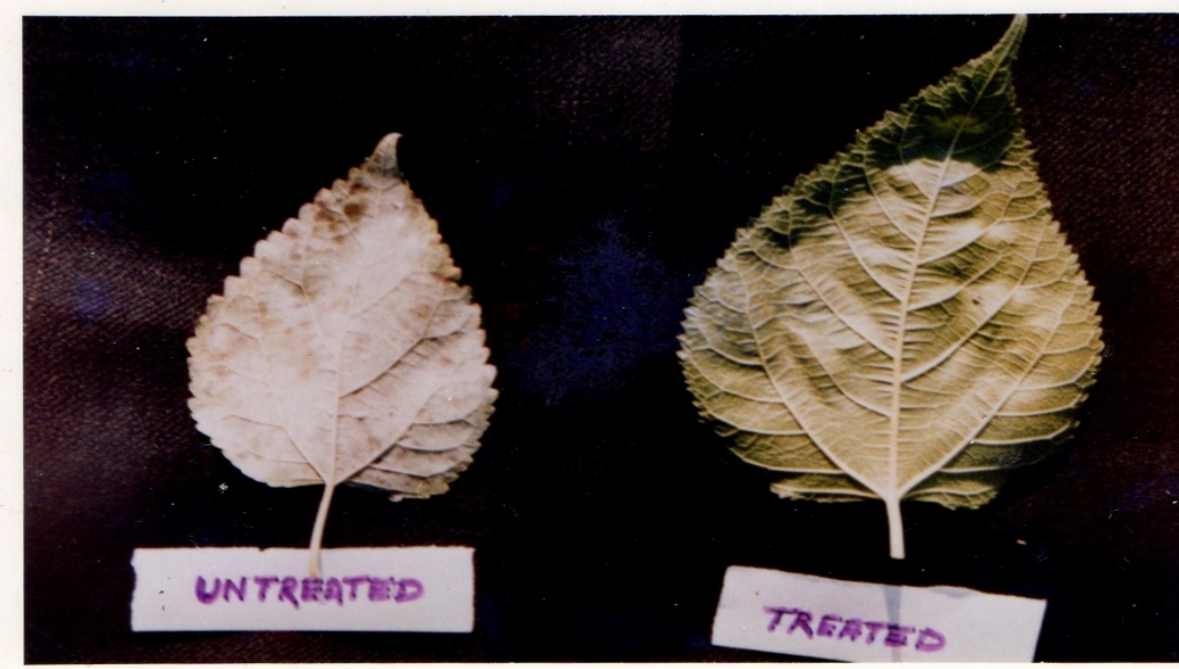

Plate- 4. Mulberry leaf infected with 'Powdery mildew'

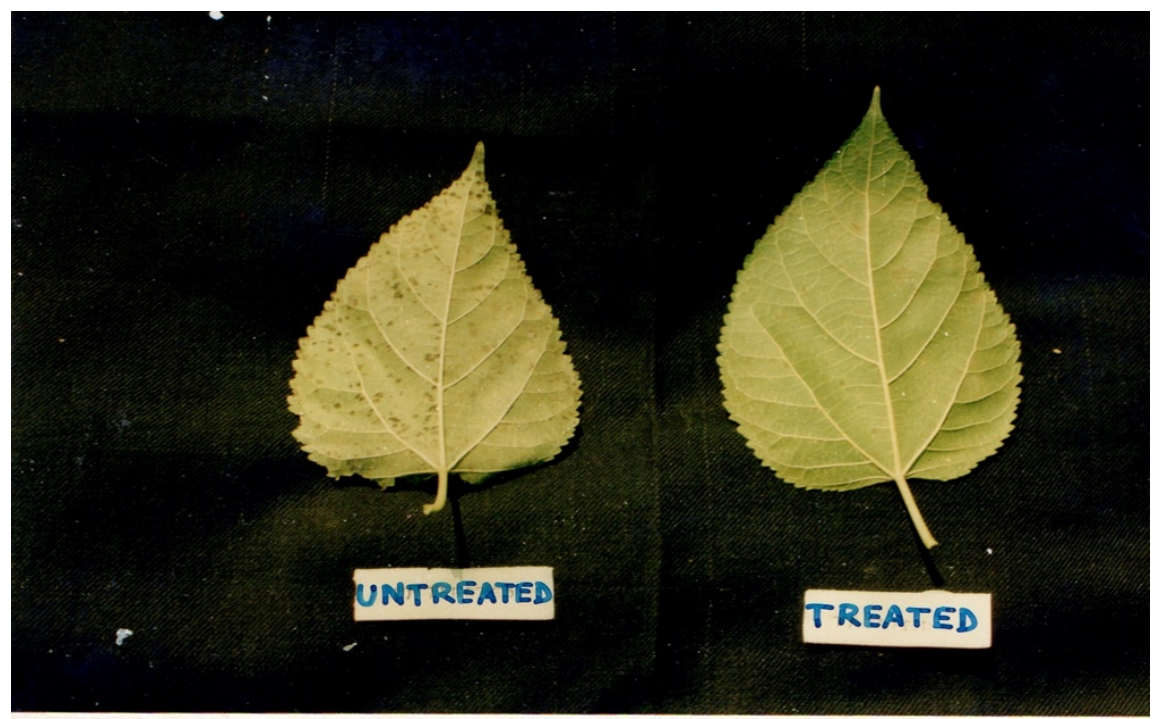

Plate- 5. Mulberry leaf infected with 'Mosaic Virus'.

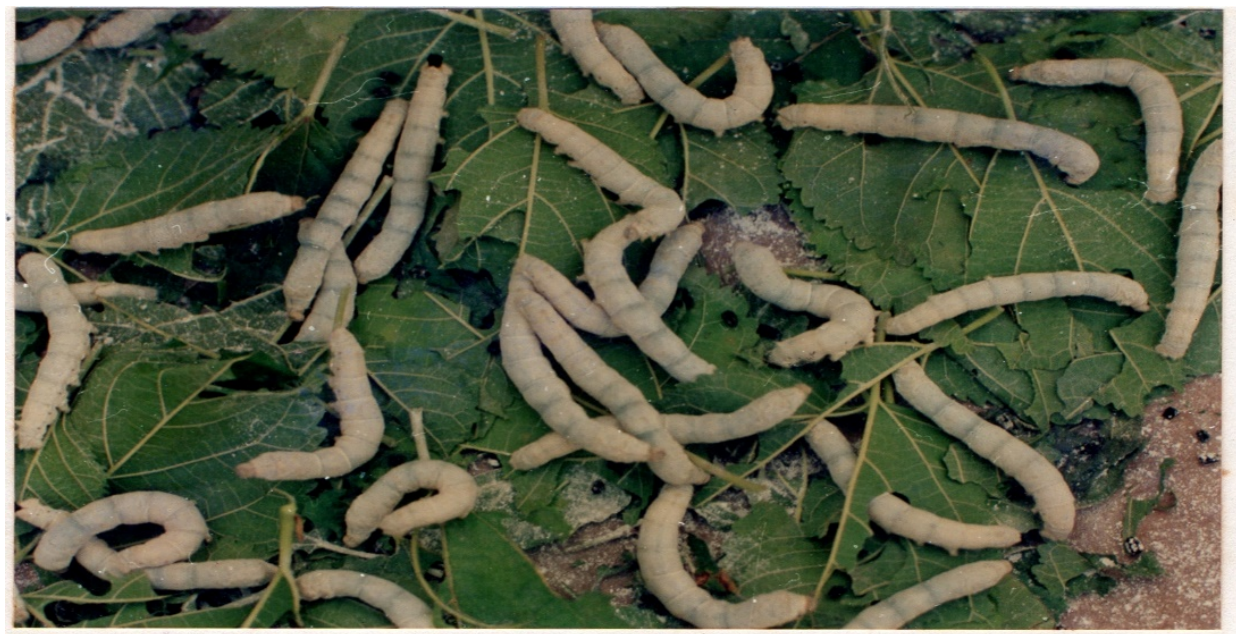

Plate- 6. 5th instar larvae of Bombyx mori L. 


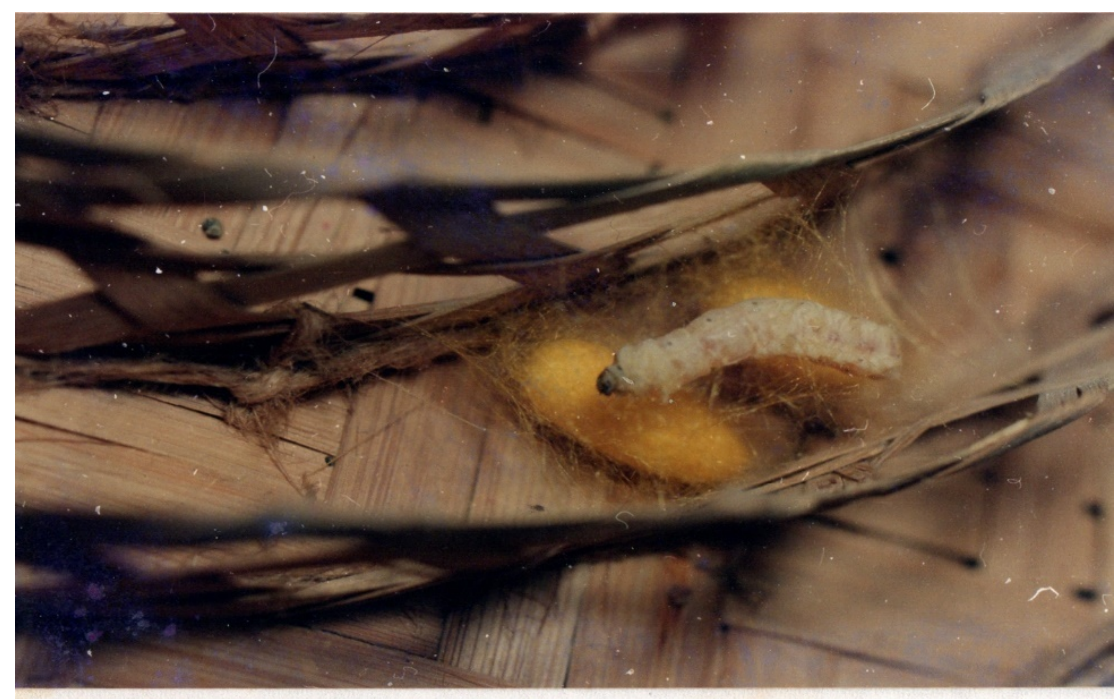

Plate- 7 . Cocoon formation by 5 th instar larvae.

Table 1: Effects of pretreatment with the ultra-high-diluted biomedicines; Cina 30C- and Cina 200C- at an extremely low dose, on root-knot diseases, Meloidogyne incognita infected mulberry plants in a field trial replicated

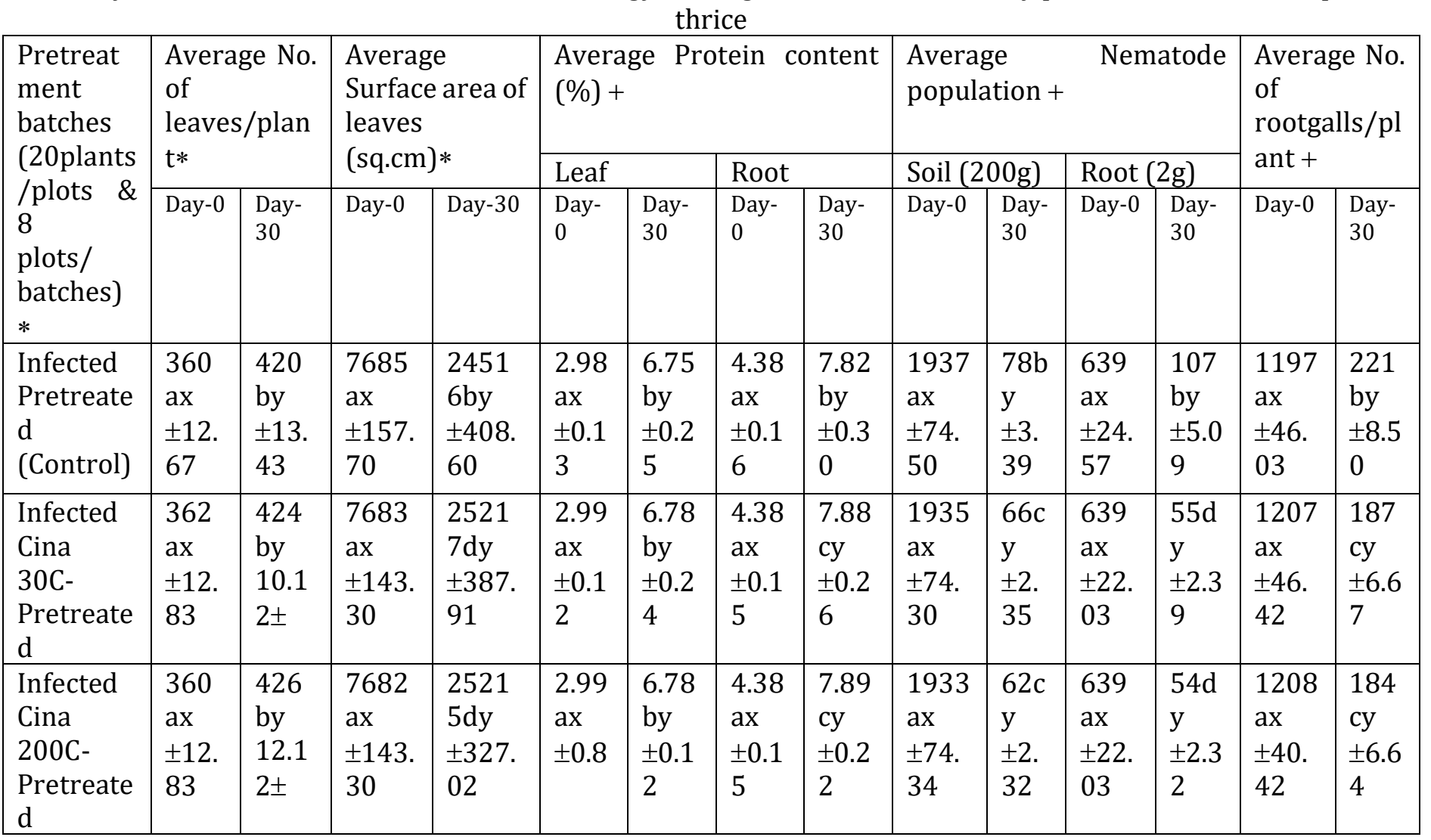

'*' - means average values of 40 plants in triplicate.

' + ' - means average values of 20 samples in triplicate.

'Day-0' - means before pretreatment.

'Day-30' - means after pretreatment.

'a,b'- significant difference by t-test $(\mathrm{P}<0.01)$ in the same column.

' $\mathrm{x}, \mathrm{y}$ '- significant difference by t-test $(\mathrm{P}<0.01)$ in the same row between day- 0 and day-30 of each character. 
Table 2: Effects of pretreatment with ultra-high-diluted biomedicines; Cina 30C- and Cina 200C- at an extremely Low dose, on leaf spot, powdery mildew, mosaic and tukra diseases of mulberry plants in a field replicated thrice assessed initially (Day-0) and after a period of 30 days (Day-30)

\begin{tabular}{|c|c|c|c|c|c|c|c|c|}
\hline \multirow{3}{*}{$\begin{array}{l}\text { Pretreatment } \\
\text { groups } \\
\text { (20 plants/ } \\
\text { Plot \& \& } \\
\text { plots/group) }\end{array}$} & \multicolumn{8}{|c|}{ Average number of disease-infected leaves / plant (\%) } \\
\hline & \multicolumn{2}{|c|}{ Leaf spot } & \multicolumn{2}{|c|}{ Powdery mildew } & \multicolumn{2}{|l|}{ Mosaic } & \multicolumn{2}{|l|}{ Tukra } \\
\hline & Day-0 & Day-30 & Day-0 & Day-30 & Day-0 & Day-30 & Day-0 & Day-30 \\
\hline $\begin{array}{l}\text { Infected } \\
\text { Pretreated } \\
\text { (Control) }\end{array}$ & $\begin{array}{l}\text { 70.58ax } \\
\pm 2.28\end{array}$ & $\begin{array}{l}\text { 98.38ay } \\
\pm 3.93 \\
(<27.80 \%)\end{array}$ & $\begin{array}{l}80.75 a x \\
\pm 3.23\end{array}$ & $\begin{array}{l}98.51 \text { ay } \\
\pm 3.94 \\
(<17.76 \%)\end{array}$ & $\begin{array}{l}\text { 68.68ax } \\
\pm 2.74\end{array}$ & $\begin{array}{l}98.05 \text { ay } \\
\pm 4.10 \\
(<29.37 \%)\end{array}$ & $\begin{array}{l}57.15 \mathrm{ax} \\
\pm 2.38\end{array}$ & $\begin{array}{l}\text { 78.35ay } \\
\pm 3.26 \\
(<21.20 \%)\end{array}$ \\
\hline $\begin{array}{l}\text { Infected Cina30C - } \\
\text { Pretreated }\end{array}$ & $\begin{array}{l}70.55 a x \\
\pm 2.31\end{array}$ & $\begin{array}{l}10.43 \text { by } \\
\pm 2.11 \\
(>60.12 \%)\end{array}$ & $\begin{array}{l}80.87 a x \\
\pm 3.01\end{array}$ & $\begin{array}{l}\text { 3.99by } \\
\pm 0.01 \\
(>76.88 \%)\end{array}$ & $\begin{array}{l}\text { 68.36ax } \\
\pm 2.42\end{array}$ & $\begin{array}{l}4.21 \text { by } \\
\pm 0.13 \\
(>64.15 \%)\end{array}$ & $\begin{array}{l}57.01 \mathrm{ax} \\
\pm 2.07\end{array}$ & $\begin{array}{l}20.69 \text { by } \\
\pm 0.11 \\
(>36.32 \%)\end{array}$ \\
\hline $\begin{array}{l}\text { Infected Cina 200C } \\
\text {-Pretreated }\end{array}$ & $\begin{array}{l}70.53 a x \\
\pm 2.71\end{array}$ & $\begin{array}{l}8.45 \text { by } \\
\pm 2.71 \\
(>62.08 \%)\end{array}$ & $\begin{array}{l}80.86 a x \\
\pm 3.11\end{array}$ & $\begin{array}{l}2.97 \text { by } \\
\pm 0.01 \\
(>77.89 \%)\end{array}$ & $\begin{array}{l}68.32 \mathrm{ax} \\
\pm 2.62\end{array}$ & $\begin{array}{l}3.41 \text { by } \\
\pm 0.13 \\
(>64.91 \%)\end{array}$ & $\begin{array}{l}57.11 \mathrm{ax} \\
\pm 2.37\end{array}$ & $\begin{array}{l}18.69 \text { by } \\
\pm 0.81 \\
(>38.42 \%)\end{array}$ \\
\hline
\end{tabular}

Day-0 means before pretreatment.

Day-30 means after pretreatment.

$a, b$ - Significant difference by ' $\mathrm{t}$ '-test $(\mathrm{P}<0.01)$ in the same column.

$\mathrm{x}, \mathrm{y}$ - Significant difference by ' $\mathrm{t}$ '- test $(\mathrm{P}<0.01)$ in the same row between day- 0 and day-30 of each character.

( )- Figures in the parentheses show percentage of reduction on day-30 as compared to the initial level on day0 in the same row.

Table 3: Pretreatment effects of disease-infected and ultra-high-diluted biomedicines; Cina 30C- and Cina 200C-pretreated at an extremely low dose, mulberry plants in a field on the feeding and growth of silkworm in the silkworms rearing trials (replicated thrice)

\begin{tabular}{|c|c|c|c|c|c|c|c|}
\hline \multirow{2}{*}{$\begin{array}{l}\text { Treatment } \\
\text { batches } \\
(180 \text { larvae/ } \\
\text { batch)* }\end{array}$} & \multicolumn{7}{|c|}{ Average number of } \\
\hline & $\begin{array}{l}\text { Consumption } \\
\text { of leaves(g) } \\
\text { (5th instar)* }\end{array}$ & $\begin{array}{l}\text { Feeding to } \\
\text { cocoon } \\
\text { formation } \\
*\end{array}$ & $\begin{array}{l}\text { Feeding- } \\
\text { day to } \\
\text { cocoon } \\
\text { formation } \\
*\end{array}$ & $\begin{array}{l}\text { Escaping } \\
\text { feeding } \\
\text { during } \\
\text { moulting* }\end{array}$ & $\begin{array}{l}\text { Moulting } \\
\text { span day } \\
\text { (1 } 1^{\text {st }} \text { to } 5^{\text {th }} \\
\text { instar }) *\end{array}$ & $\begin{array}{l}\text { Larval fresh } \\
\text { weight }(g) \\
\left(5^{\text {thinstar }) *+}\right.\end{array}$ & $\begin{array}{l}\text { Mortality } \\
\text { rate }(\%) *\end{array}$ \\
\hline $\begin{array}{l}\text { Infected } \\
\text { Pretreated } \\
\text { (Control) } \\
\end{array}$ & $\begin{array}{l}4.03 a \\
\pm 0.15\end{array}$ & $\begin{array}{l}76.00 \mathrm{a} \\
\pm 2.37\end{array}$ & $\begin{array}{l}19.00 \mathrm{a} \\
\pm 0.50\end{array}$ & $\begin{array}{l}51.00 \mathrm{a} \\
\pm 1.75\end{array}$ & $\begin{array}{l}13.00 \mathrm{a} \\
\pm 0.39\end{array}$ & $\begin{array}{l}1.48 \mathrm{a} \\
\pm 0.03\end{array}$ & $\begin{array}{l}56.00 \\
\pm 2.43\end{array}$ \\
\hline $\begin{array}{l}\text { Infected } \\
\text { Cina 30C } \\
\text { Pretreated }\end{array}$ & $\begin{array}{c}2.46 \mathrm{~b} \\
\pm 0.09\end{array}$ & $\begin{array}{l}62.00 \mathrm{~b} \\
\pm 1.93\end{array}$ & $\begin{array}{l}15.00 \mathrm{~b} \\
\pm 0.44\end{array}$ & $\begin{array}{l}20.00 \mathrm{~b} \\
\pm 0.68\end{array}$ & $\begin{array}{l}5.00 \mathrm{~b} \\
\pm 0.15\end{array}$ & $\begin{array}{l}2.63 \mathrm{~b} \\
\pm 0.06\end{array}$ & Nil \\
\hline $\begin{array}{l}\text { Infected } \\
\text { Cina 200C } \\
\text {-Pretreated } \\
\end{array}$ & $\begin{array}{l}2.42 \mathrm{~b} \\
\pm 0.04\end{array}$ & $\begin{array}{l}60.00 \mathrm{~b} \\
\pm 1.92\end{array}$ & $\begin{array}{l}15.00 \mathrm{~b} \\
\pm 0.40\end{array}$ & $\begin{array}{l}20.00 \mathrm{~b} \\
\pm 0.62\end{array}$ & $\begin{array}{l}5.00 \mathrm{~b} \\
\pm 0.13\end{array}$ & $\begin{array}{l}2.61 b \\
\pm 0.05\end{array}$ & Nil \\
\hline
\end{tabular}

a,b- different small letters in a column show significant difference by ' $\mathrm{t}$ '- test $(\mathrm{P}<0.01)$.

* - average values of 180 silk worm larvae in triplicate.

+ - average values of 10 silk worm larvae were dissected in triplicate. 
Table 4: Pretreatment effects of disease-infected, and ultra-high-diluted biomedicines; Cina 30C- and Cina 200Cpretreated at an extremely low dose, mulberry plants in a field on the growth of silk gland, spinning time, cocoon, shell, rearing, sex ratio and egg laying capacity in the silkworms rearing trials (replicated thrice)

\begin{tabular}{|l|l|l|l|l|l|l|l|l|l|}
\hline \multirow{2}{*}{$\begin{array}{l}\text { Pretreatment } \\
\text { batches } \\
\begin{array}{l}180 \text { larvae/ } \\
\text { batch)* }\end{array}\end{array}$} & \begin{tabular}{l} 
Average \\
\cline { 2 - 9 } \\
fresh \\
weight(g) \\
$\left(5^{\text {th }}\right.$ \\
instar)+
\end{tabular} & $\begin{array}{l}\text { Starting } \\
\text { time to } \\
\text { spinning } \\
\text { (at day- } \\
\text { )* }\end{array}$ & $\begin{array}{l}\text { Span of } \\
\text { spinning } \\
\text { day* }\end{array}$ & $\begin{array}{l}\text { Cocoon } \\
\text { fresh } \\
\text { weight } \\
(\mathrm{g}) *\end{array}$ & $\begin{array}{l}\text { Shell } \\
\text { fresh } \\
\text { weight } \\
\text { (g) }+\end{array}$ & $\begin{array}{l}\text { Shell } \\
\text { ratio } \\
\text { (SR\%) } \\
+\end{array}$ & $\begin{array}{l}\text { Effective } \\
\text { rate of } \\
\text { rearing } \\
\text { (ERR\%)* }\end{array}$ & $\begin{array}{l}\text { Sex ratio } \\
\text { (Male } \\
\text { Female\%) }\end{array}$ & $\begin{array}{l}\text { Egg } \\
\text { laying } \\
\text { capasity }\end{array}$ \\
\hline $\begin{array}{l}\text { Infected } \\
\begin{array}{l}\text { Pretreated } \\
\text { Control) }\end{array}\end{array}$ & $\begin{array}{l}0.98 \mathrm{a} \\
\pm 0.03\end{array}$ & $\begin{array}{l}34.00 \mathrm{a} \\
\pm 1.30\end{array}$ & $\begin{array}{l}10.00 \mathrm{a} \\
\pm 0.45\end{array}$ & $\begin{array}{l}0.85 \mathrm{a} \\
\pm 0.03\end{array}$ & $\begin{array}{l}0.11 \mathrm{a} \\
\pm 0.01\end{array}$ & $\begin{array}{l}12.94 \mathrm{a} \\
\pm 0.49\end{array}$ & $\begin{array}{l}21.37 \mathrm{a} \\
\pm 0.63\end{array}$ & $\begin{array}{l}76.00 \mathrm{a} \\
\pm 1.94\end{array}$ & $\begin{array}{l}320.00 \mathrm{a} \\
\pm 13.91\end{array}$ \\
\hline $\begin{array}{l}\text { Infected } \\
\begin{array}{l}\text { Cina } \\
\text {-Pretreated }\end{array}\end{array}$ & $1.98 \mathrm{~b}$ & $\begin{array}{l}20.00 \mathrm{~b} \\
\pm 0.51\end{array}$ & $\begin{array}{l}3.00 \mathrm{~b} \\
\pm 0.09\end{array}$ & $\begin{array}{l}1.09 \mathrm{~b} \\
\pm 0.04\end{array}$ & $\begin{array}{l}0.24 \mathrm{~b} \\
\pm 0.02\end{array}$ & $\begin{array}{l}22.01 \mathrm{~b} \\
\pm 0.67\end{array}$ & $\begin{array}{l}97.43 \mathrm{~b} \\
\pm 2.16\end{array}$ & $\begin{array}{l}68.00 \mathrm{~b} \\
\pm 1.74\end{array}$ & $\begin{array}{l}540.00 \mathrm{~b} \\
\pm 11.73\end{array}$ \\
\hline $\begin{array}{l}\text { Infected } \\
\text { Cina 200C } \\
\text {-Pretreated }\end{array}$ & $\begin{array}{l}1.98 \mathrm{~b} \\
\pm 0.04\end{array}$ & $\begin{array}{l}20.00 \mathrm{~b} \\
\pm 0.42\end{array}$ & $\begin{array}{l}3.00 \mathrm{~b} \\
\pm 0.06\end{array}$ & $\begin{array}{l}1.09 \mathrm{~b} \\
\pm 0.02\end{array}$ & $\begin{array}{l}0.24 \mathrm{~b} \\
\pm 0.01\end{array}$ & $\begin{array}{l}22.01 \mathrm{~b} \\
\pm 0.42\end{array}$ & $\begin{array}{l}97.48 \mathrm{~b} \\
\pm 2.16\end{array}$ & $\begin{array}{l}68.00 \mathrm{~b} \\
\pm 1.72\end{array}$ & $\begin{array}{l}540.00 \mathrm{~b} \\
\pm 11.71\end{array}$ \\
\hline
\end{tabular}

a,b- different small letters in a column show significant difference by ' $\mathrm{t}$ '- test $(\mathrm{P}<0.01)$.

* - average values of 180 silk worm larvae in triplicate.

+ - average values of 10 silk worm larvae and cocoon were dissected in triplicate.

\section{SOURCES OF FUNDING}

This research received no specific grant from any funding agency in the public, commercial, or not-for-profit sectors.

\section{CONFLICT OF INTEREST}

The author have declared that no competing interests exist.

\section{ACKNOWLEDGMENT}

The work has been supported by Prof. N.C.Sukul and Prof. S.P.Sinha Babu, Department of Zoology, Visva-Bharati, and Joint Director, Sriniketan Sericultural Composite Unit. I am thankful to the eminent Senior Consultant Physician \& Cardiologist Dr. Tushar Kanti Batabyal, M.B.B.S., M.D., Ex-Clinical Tutor of the Burdwan Medical College \& Hospital, for inspiration and guidance. I express my deep gratitude to Mr. Rakesh Khan, Secretary and Mr. Subhendu Bose, President with all Young Green-Members of the "International NGO named Burdwan Green Haunter and Students' Goal" for arranging to many awareness programmed on COVID-19. Last but not the least, I am thankful to the eminent educationist Sri Tapaprakash Bhattacharya for inspiration and guidance.

\section{REFERENCES}

[1] Teotia RS, Sen SK. Mulberry disease in India and their control. Sericologia 1994; 34:1-18.

[2] Datta SC, Sinhababu SP, Sukul NC. Improved growth of silkworms from effective treatment of mulberry diseases by Acacia auriculiformis extract. Sericologia 1997; 37:707-715.

[3] Datta SC. Bio-nematicides in the control of root-knot nematode. Ph.D. thesis, Department of Zoology, VisvaBharati, Santiniketan-731235, West Bengal, India 1999 (unpublished).

[4] Datta SC. Plant Parasitic nematodes - an agricultural problem and its solutions. Visva-Bharati Quarterly 2005; 11:89-100. 
Subhas Chandra Datta, Ph.D.

[5] Datta SC. Effects of Cina on root-knot disease of mulberry. Homeopathy 2006a; 95:98-102.

[6] Datta SC. Possible use of amaranth as catch crop for root-knot nematodes intercropped with okra. Phytomorphology 2006b; 56:113-116.

[7] Datta SC, Datta R. Liquid homeopathic medicine Cina enriches sericulture industry. Journal of Environmental \& Sociobiology 2006; 3:55-60.

[8] Datta SC, Datta R. Increased silk production by effective treatment of naturally infected root-knot and black leaf spot diseases of mulberry with acaciasides. Journal of Environmental \& Sociobiology 2007a; 4:209-214.

[9] Datta SC, Datta R. Intercropping amaranth with mulberry for managing root-knot nematodes and improving sericulture. Sericologia 2007b; 47(3):297-302.

[10] Datta SC. Mulberry disease: Problem in sericulture. SEBA NEWSLETTER, Environment \& Sociobiology 2007;4:7-10.

[11] Datta SC, Datta R. Potentized Artemisia nilagirica extract Cina increases silk production and effective rate of rearing in a field trial. Hpathy Ezine 2008.

[12] Datta SC. The Role of Cina in the Field of Enriched Sericulture. Hpathy Ezine 2010.

[13] Datta SC, Datta R. Control root-knot disease of mulberry by homeopathic medicines: Aakashmoni [MT, 30C, 200C \& 1000C] prepared from the funicles of Acacia auriculiformis. Hpathy Ezine 2011a.

[14] Datta SC, Datta R. Homeopathic Medicines Protect Environment, Health and Development by Controlling Mulberry Diseases. JJ Homeop Ayurv Med 2011b; 1:104. doi:10.4172/2167-1206.1000104.

[15] Datta SC, Datta R. Homeopathic Medicines Protect Environment, Health and Development by Controlling Mulberry Diseases. Journal of Traditional Medicine \& Clinical Naturopathy 2012a; 1: 104.

[16] Datta SC, Datta R. Homeopathic medicine Aakashmoni 200C control mulberry diseases enriching sericulture. J. Curr. Chem Pharm Sc 2012b; 2:37-49.

[17] Datta SC, Datta R. Efficacy of pure compound- acaciasides A and B as potential bioagents against various plant pathogens. Journal of Environment \& Sociobiology 2012c; 9(1):17-26.

[18] Datta SC, Datta R. Efficacy of homeopathic medicine-Aakashmoni as potential bio-agent against various plant pathogens. J Biochem \& Pharmacol 2013; 2:4. http://dx.doi.org/10.4172/2167-0501.S1.004.

[19] Datta SC, Das R, Chatterjee K, Mondal B, Das R. Amaranth Plant: Protects Climate, Health and Development by Controlling Root-Knot Disease. Journal of Environmental \& Analytical Toxicology 2016; 6:341.

[20] Datta SC, Datta R. Prevention and control of root-knot disease of mulberry plants using bioagents amaranth plants: improving sericulture by protecting climate health, health and development. J Environ \& Sociobiol 2016a; 13:191-200.

[21] Datta SC, Datta R. Acaciasides use as Potential Bio-Agents against Various Plant Pathogens. Book: New Innovations in Environmental Biotechnology. Publisher: Lenin Media Delhi Pvt.Ltd. Delhi, Chapter 14, 2016; Pages-20, Editors: Dr. M.M. Abid Ali Khan (India), Murtaza Abid (India), Dr. Abdeen Mustafa Omer (United Kingdom), Dr.Binna Rani (India) 2016b.

[22] Datta SC. Enriched Sericulture from Effective Treatment of Mulberry Diseases by Homeopathic Medicines. Adv Biochem Biotechnol 2019a; 7:084. DOI: 10.29011/2574-7258.000084.

[23] Datta SC. Improved Environment by Identification of More Susceptible Plant Between Cowpea and Mulberry for Root-Knot Disease. Open Access Journal of Environmental Soil Science 2019b;2(5):242-245. DOI: 10.32474/OAJESS.2019.02.000148.

[24] Datta SC. Enriched Science and Technology Communication Economy in Agriculture by Use of Acacia sides as Potential Bio-Agents against Various Pathogens. Advances in Agriculture, Horticulture and Entomology 2020;2:1-13.

[25] Sukul NC, Sinhababu SP, Datta SC, Nandi B, Sukul A. Nematotoxic effect of Acacia auriculiformis and Artemisia nilagirica against root-knot nematodes. Allelopathy Journal 2001; 8: 65-72.

[26] Govindaiah, Sharma DD. Root-knot nematode, Meloidogyne incognita infesting mulberry - a review. Indian Journal of Sericulture 1994; 33:110-113.

[27] Gunasekhar V, Govindaiah, Datta RK. Occurrence of Altemaria Leaf blight of mulberry and a key for disease assessment. Int J Tropical Plant Dis 1994; 12:53-57.

[28] Sukul NC. Plants antagonistic to plant parasitic nematodes. Indian Review of Life Science 1992; 12:23-52.

[29] Christie JR, Perry VG. Removing nematodes from soil. Proceeding of Helminthological Society, Washington 1951;18:106-108. 
Biomedicines-Cina Against Covid-19: Controlled Plant Diseases Enriched Science and Technology Communication Green Economy

[30] James WC. An illustrated series of assessment keys for plant diseases, their preparation and usage. Can Plant Disease Surv 1971; 51:39-65.

[31] Chatterjee A, Sukul NC. Total protein of galled roots as an index of root-knot nematode infestation of lady's finger plants. Phytopathology 1981; 71:372-274.

[32] Lowry OH, Rossebrough NJ, Farr AR, Randall RJ. Protein measurement with the Folin-phenol reagent. Journal of Biological Chemistry 195; 193:265-275.

[33] Anonymous. The American Homeopathic Pharmacopoeia. 9th edn, Philadelphia, USA: Boericke and Tafel 1920.

[34] Datta SC, Datta R, Sinhababu SP, Sukul NC. Acaciasides and root-knot nematode extract suppress Melodogyne incognita infection in lady's finger plants. Proceeding of the National Seminar on Environmental Biology 1998; 98:205-209.

[35] Valipour M. What is the tendency to cultivate plants for designing cropping intensity in irrigated area? Adv in Water Sci and Tech 2015a; 01:01-12.

[36] Valipour M. Assessment of Important Factors for Water resources Management in European Agriculture. J of Water Resource and Hydraulic Eng 2015b;4(2):171-180

[37] WHO. Coronavirus disease (COVID-2019) An international randomised trial of candidate vaccines against COVID-19 version. World Health Organization's, R\&D Blueprint 19 April 2020. https://www.who.int/blueprint/priority-diseases/key-action/novel-coronavirus/en/

[38] Filetti S. The COVID-19 pandemic requires a unified global response. Springer Science Business Media, LLC, part of Springer Nature, Endocrine 2020. https://doi.org/10.1007/s12020-020-02293-6.

[39] Chen Y, Liu Q, Guo D. Emerging coronaviruses: Genome structure, replication, and pathogenesis. J Med Virol 2020; 92:418-423. https://doi.org/10.1002/jmv.25681.

[40] Science Daily. The genetic quest to understand COVID-19: Unlocking the genetic code of the novel coronavirus will help us prevent other diseases. Science Daily, Science News, University of Sydney 26 March 2020. <www.sciencedaily.com/releases/2020/03/200326144357.htm>.

[41] Julka A. Coronavirus India News Live Updates 24 April 2020: COVID-19 Cases Soar Past 24000. Grain Mart News, April 24, 2020.

[42] Anand K, et al. Structure of coronavirus main proteinase reveals combination of a chymotrypsin fold with an extra $\alpha$-helical domain. The EMBO Journal 2002; 21:3213-3224.

[43] Yang HT, et al. The crystal structures of severe acute respiratory syndrome virus main protease and its complex with an inhibitor. Proceedings of the National Academy of Sciences of the United States of America 2003; 100:13190-13195, https://doi.org/10.1073/pnas.1835675100.

[44] Buschman E, Skamene E. Genetic Resistance to Coronavirus Infection- A Review. Part of the Advances in Experimental Medicine and Biology book series, Springer Nature Switzerland 2019;380:1-11.

[45] Roujian L, Xiang Z, Juan L, Peihua N, Bo Y, Honglong W, et al. Genomic characterisation and epidemiology of 2019 novel coronavirus: implications for virus origins and receptor binding. 2020; l 395: 565-574. www.thelancet.com.

[46] IUCN. Guidelines on the conservation of medicinal plants. The International Union for Conservation of Nature and Natural Resources, World Health Organization and World-Wide Fund for Nature. Gland, Switzerland1993.

[47] Mukewar P. Trade in the time of COVID-19: The economic impact of coronavirus on India and beyond. India Today, New Delhi March 29, 2020.

[48] Cohen J. United States should allow volunteers to be infected with coronavirus to test vaccines, lawmakers argue. Science, Posted in: Health Science and Policy Coronavirus. Apr. 21, 2020. doi:10.1126/science.abc3772.

[49] Servick K. Antimalarials widely used against COVID-19 heighten risk of cardiac arrest. How can doctors minimize the danger? Science,Posted in: Health Coronavirus 2020. doi:10.1126/science.abc3816.

[50] Datta SC, Datta R, Sukul A, Sukul NC, Sinhababu SP. Relative attractiveness of four species of vegetable crops for Meloidogyne incognita. Environ Ecol 2000; 18:233-235.

[51] Datta SC, Sinhababu SP, Banerjee N, Ghosh K, Sukul NC. Melodogyne incognita extract reduces Melodogyne incognita infestation in tomato. Indian J Nematol 1998; 28:1-5.

[52] Datta SC, Datta R, Sinhababu SP, Sukul NC. Acaciasides and root-knot nematode extract suppress Melodogyne incognita infection in lady's finger plants. Pro Nat Sem Environ Biol 1998; 98:205-209. 
[53] Datta SC. Improved midday meal by using cowpea as eco-friendly crop controlling root-knot forming global, green, growth and green economy. International Journal of Advanced Research (Accepted) 2019c.

[54] Mohanty B, Puri S, Kesavan V. A Review on Therapeutic Potential of Artemisia nilagirica. J Plant Biochem Physiol 2018; 6:205. doi:10.4172/2329-9029.1000205.

[55] Panda S, Rout JR, Pati P, Ranjit M, Sahoo SL. Antimalarial activity of Artemisia nilagirica against Plasmodium falciparum. J Parasit Dis 2018;42(1):22-27. https://doi.org/10.1007/s12639-017-0956-9

[56] Arokiyaraj S, Sripriya N, Bhagya R, Radhika B, Prameela L, et al. Phytochemical screening, antibacterial and free radical scavenging effects of Artemisia nilagirica, Mimosa pudica and Clerodendrum siphonanthus-An in vitro study. Asian Pacific Journal of Tropical

Biomedicine 2012; 29: S601-S604.

[57] Ahameethunisa AR, Hopper W. Antibacterial activity of Artemisia nilagirica leaf extracts against clinical and phytopathogenic bacteria. BMC Complementary and Alternative Medicine 2010; 29:6.

[58] Suseela V, Gopalakrishnan VK, Varghese S. In vitro antioxidant studies of fruits of Artemisia nilagirica (Clarke) Pamp. Indian Journal of Pharmaceutical Sciences 2010; 72:644.

[59] Sukul NC. Control of plant parasitic nematodes by plant substances. Allelopathy in Agriculture and Forestry, (Edited by S.S. Narwal and P. Tauro), Scientific Publisher, Jodhpur, India 1994;183-211.

[60] Sukul NC, Sukul A. High Dilution Effects: Physical and Biochemical Basis. Authors Nirmal C. Sukul, Anirban Sukul Copyright 2005 Publisher Springer Netherlands Copyright Holder, Springer Science \& Business Media B.V. eBook Edition Number 1Number of Pages XII, 130.

ISBN 978-1-4020-2156-5 DOI 10.1007/1-4020-2156-9, Hardcover ISBN 978-1-4020-2155-8 Softcover ISBN 978-90-481-6601-5.

[61] Fenner LM. Determination of nematode mortality. Plant Disease Reporter 1962;46: 383.

[62] Sukul NC. Soil and plant nematodes. West Bengal State Book Board Publisher 1987; pp. 1-271.

[63] Sengupta K, Govindaiah, Pradip K, Murthuza B. Hand book on pest and disease control of mulberry and silkworm- Disease of mulberry and their control. United Nations Economic and Social Commission for Asia and Pacific, Bangkok, Thailand 1990; pp. 1-14.

[64] James WC. An illustrated series of assessment keys for plant diseases, their preparation and usage. Canadian Plant Disease Survey 1971;51(2):39-65.

[65] Allen SJ, Brown JF, Kochman JK. Production of inoculum and field assessment of Atemaria helianthi on sunflower. Plant Disease 1983;67(8):665-668.

[66] Datta SC. Enriched School Health for The Effective Healthcare Bio-Activity of Barn Owls. Research \& Review of Health Care Open Access Journal 2019d;3(3):269-275. doi: 10. 32474.RRHOAJ.2019.03.000164.

[67] Datta SC. Enriched School Environment for the Effective Bio-Activity of Barn Owls. International journal of Horticulture, Agriculture and Food science (IJHAF) 2019e;3(3):119-126, ISSN: 2456-8635. https://dx.doi.org/10.22161/ijhaf.3.3.2.

[68] Field B, Jordan F, Osbourn A. First encounters - development of defence - related natural products by plants. New Phytologist 2006; 172:193-207.

[69] Klessig, Daniel F, Malamy J. The salicylic acid signal in plants. Plant Molecular Biology 1994; 26:1439-1458.

[70] Das S, Sukul NC, Mitra D, Sarkar H. Distribution of lectin in nematode infested and uninfested roots of Hibiscus esculentus. Nematologica Mediterranea 1989; 17:123-125.

[71] Mauch-Mani B, Metraux JP. Salicylic acid and systemic acquired resistance to pathogen attack. Annals of Botany 1998; 82:535-540.

[72] Nandi B, Kundu K, Banerjee N, Sinhababu SP. Salicylic acid -induced suppression of Meloidogyne incognita infestation of okra and cowpea. Nematology 2003; 5:747-752.

[73] Ross AF. Systemic acquired resistance induced by localized virus infection in plants. Virology 1961; 14:340358.

[74] Osbourn AE, Clarke BR, Lunness P, Scott PR, Daniels MJ. An oat species lacking avenacin is susceptible to infection by Gaeumannomyces graminis var. tritici. Physiological and Molecular Plant Pathology 1994;45: 457-467.

[75] Jasinski M, Stukkens Y, Degand H, Purnelle B, Marchand-Brynaert J, Boutry M. A plant plasma membrane ATP binding cassette-type transporter is involved in antifungal terpenoid secretion. Plant Cell 2001; 13:10951107. 
Biomedicines-Cina Against Covid-19: Controlled Plant Diseases Enriched Science and Technology Communication Green Economy

[76] Stukkens Y, Bultreys A, Grec S, Trombik T, Vanham D, Boutry M. NpPDRI, a pleiotropic drug resistance-type ATP-binding cassette transporter from Nicotiana plumbaginifolia, plays a major role in plant pathogen defense. Plant Physiology 2005;139: 341-352.

[77] McClure MA, Misaghi I, Night Edward LJ. Shared antigens of parasitic Nematodes and Host plants. Nature 1973;244: 306.

[78] Osbourn AE. Saponins and plant defence- a soap story. Trends in Plant Science 1996; 1:4-9.

[79] Papadopoulou K, Melton RE, Leggett M, Daniels MJ, Osbourn AE. Compromised disease resistance in saponindeficient plants. Proceedings of the National Academy of Science, USA 1999;96:12923-12928.

[80] Osbourn AE, Qi X, Townsend B, Qin B. Secondary metabolism and plant defence. New Phytologist 2003; 159:101-108.

[81] Sasser JN, Freckman DW. Proceedings of 25th Annual Meeting Society of Nematologists, Orlando, Florida 1986;86:32.

[82] Datta SC, Datta R. Defence resistance of okra against root-knot disease by bio-nematicides. Proceedings of the Zoological Society,Calcuutta University,Calcutta, West Bengal 2000;59(2):75-82.

[83] Zarter CR, Demmig-Adams B, Ebbert V, Adamska I, Adams WW III. Photosynthetic capacity and light harvesting efficiency during the winter-to-spring transition in subalpine conifers. New Phytologist 2006; 172:283-292.

[84] Williams SCP. Humans may harbor more than 100 genes from other organisms. Science, Posted in: Biology 2015. doi:10.1126/science. aab0307.

[85] Zhou P, et al. A pneumonia outbreak associated with a new coronavirus of probable bat origin. Nature Medline 2020; 579:270-273. doi:10.1038/s41586-020-2012-7.

[86] Wu F, et al. A new coronavirus associated with human respiratory disease in China. Nature Medline 2020; 579:265-269. doi:10.1038/s41586-020-2008-3.

[87] Lu R, et al. Genomic characterisation and epidemiology of 2019 novel coronavirus: Implications for virus origins and receptor binding. Lancet Medline 2020; 395:565-574. doi:10.1016/S0140-6736(20)30251-8.

[88] Appels R, Nystrom J, Webster H, Keeble-Gagnere G. Discoveries and advances in plant and animal genomics. Funct Integr Genomics 2015; 15:121-129. doi:10.1007/s10142-015-0434-3.

[89] Science Daily. Our complicated relationship with viruses. Science NewsNIH, National Institute of General Medical Sciences (NIGMS) 2016.

[90] On Biology. The viral content of human genomes is more variable than we thought. Rebecca Pearce, Journal Development Manager at BMC, Blog Network 2019.

[91] Callif BL. The Human Genome Is Full of Viruses. Medium, Medical Myths and Models 2020.

[92] Zhang LK, et al. Structure-based design of antiviral drug candidates targeting the SARS-CoV-2 main protease. Cite as: W. Dai et al., Science 2020;10.1126/science. abb4489. http://science.sciencemag.org/content/early/2020/04/21/science.abb4489.

[93] Speiser J. The COVID-19 Disease and Our Genes. Ken Burns, A special post from guest writer Joshua Speiser, The Gene 7th April, 2020.

[94] Sati SC, Sati N, Ahluwalia V, Walia S, Sati OP. Chemical composition and antifungal activity of Artemisianilagirica essential oil growing in northern hilly areas of India. Journal Natural Product Research, Formerly Natural Product Letters 2013;27(1):45-8. doi: 10.1080/14786419.2011.650636.

[95] Pandey AK, Singh P.The Genus Artemisia: A 2012-2017 Literature Review on Chemical Composition, Antimicrobial, Insecticidal and Antioxidant Activities of Essential Oils. Medicines (Basel) 2017;4(3):68. doi: 10.3390/medicines4030068.

[96] Jiang Z, Guo X, Zhang K, Sekaran G, Cao B, Zhao Q, Zhang S, Kirby GM and Zhang X. The Essential Oils and Eucalyptol from Artemisia vulgaris L. Prevent Acetaminophen-Induced Liver Injury by Activating Nrf2-Keap1 and Enhancing APAP Clearance Through Non-Toxic Metabolic Pathway. Front. Pharmacol 2019; 10:782. doi: 10.3389/fphar.2019.00782

[97] Times of India. Covid-19: WHO cautions against untested traditional remedies. The World Health Organization (WHO), Paris, 4th May 2020.

[98] Said N. Coronavirus COVID-19: Available Free Literature Provided by Various Companies, Journals and Organizations around the World. Ongoing Chemical Research 2020;5(1):7-13. doi:10.5281/zenodo.3722904. 
[99] News Drug Target Review's. Coronavirus update: recent developments in vaccine Research. Drug Target Review's round-up of the latest developments in 2019 novel coronavirus (COVID-19 or SARS-CoV-2) therapeutics and vaccines 27th February 2020.

[100] Joshi T, Joshi T, Sharma P, Mathpal S, Pundir H, Bhatt V, Chandra S. In silico screening of natural compounds against COVID-19 by targeting Mpro and ACE2 using molecular docking. European Review for Medical and Pharmacological Sciences 2020; 24:4529-4536.

[101] Sweeney C. Human Immunomics Initiative will decode immune system, speed new vaccines. Harvard T.H. Chan School of Public Health News, April 14, 2020, Copyright (C) 2020 The President and Fellows of Harvard College csweeney@hsph.harvard.edu,617.549.2638. https://www.hsph.harvard.edu.

[102] WHO. Vaccine-preventable diseases and vaccines. International travel and health Chapter 2020; 6:1-61, See country list updated yearly on WHO's ITH web page at: http://www.who.int /ith/en/ http://www.who.int/immunization_standards/vaccine_quality/PQ_vaccine_list_en/en/.

[103] Bougrine R, Hdidou Y, Aissaoui H, Elouafi N, Ismaili N. Emergency stay triggered Tako-Tsubo syndrome: A case report and review of the literature. Glob J Medical Clin Case Rep 2019;6(2):035-038. DOI: https://dx.doi.org/10.17352/2455-5282.000077.

[104] Hoffmann M, Kleine-Weber H, Schroeder S, et al. SARSCoV-2 cell entry depends on ACE2 and TMPRSS2 and is blocked by a clinically proven protease inhibitor. Cell 2020;181(2): 271-280.

[105] Soler MJ, Barrios C, Oliva R, Batlle D. Pharmacologic modulation of ACE2 expression. Curr Hypertens 2008; 10:410-4.

[106] John AJ, Julie RI, Beth HM, D’Agostino BR, Harrington PD. Inhibitors of the Renin-Angiotensin-Aldosterone System and Covid-19. The new England Journal o f Medicine. Copyright (C) 2020 Massachusetts Medical Society. This editorial was published at NEJM.org. on May 1, 2020.

[107] The Times of India. Homeopathy, ayurveda docs want a chance to treat Covid-19. RANCHI: TOI, TNN, May 11, 2020.

[108] Merck JCJ. One of Big Pharma's biggest players, reveals its COVID-19 vaccine and therapy plans. Science's COVID-19 reporting is supported by the Pulitzer Center, Science, Science Mag.org. 26May, 2020.

[109] Wigginton NS, Cunningham RM, Katz RH, Lidstrom ME, Moler KA, Wirtz D, Zuber MT. Moving academic research forward during COVID-19. POLICY FORUM, Science, Science Mag.org. 28 May 2020: eabc5599. DOI: 10.1126/science.abc5599

[110] Stone R. Yemen was facing the world's worst humanitarian crisis. Then the coronavirus hit. Science, Science's COVID-19 reporting is supported by the Pulitzer Center, Science Mag.org. May. 28, 2020.

[111] Parks JM, Smith JC. How to Discover Antiviral Drugs Quickly. The New England Journal of Medicine, nejm.org. Copyright (C) 2020 Massachusetts Medical Society. May 20, 2020. doi: 10.1056/NEJMcibr2007042.

[112] Kupferschmidt K. Can plasma from COVID-19 survivors help save others? Science's COVID-19 reporting is supported by the Pulitzer Center. ScienceMag.org., Science May 27, 2020.

[113] Gilmore K. Artemisia annua to be tested against COVID-19. ArtemiLife Inc., a US based company, CEO Adam Maust in Artemisia annua fields 2020.

[114] Staff Reporter. Corona Vaccine will be prepared from the extract of fruits of Aakashmoni plants- Opinion of the researcher of Burdwan. Agnirath News, Burdwan, 15th April 2020;21(8):1-3. Reg.No.WBBEN/2000/2086.

[115] The Science Advisory Board Net. Fighting SARS-CoV-2 at the bench? Express Cells has your back. Letter Science Advisory Board.Net on Fri, 24 Apr 2020;18:30:49. <letters@scienceboard.net>

[116] Dutta PK. Covid Toes among kids: New symptom of novel coronavirus infection. News India Today, New Delhi 24th April 2020.

[117] Rajput H. Homeopathic Prophylaxis: Just Homeopathic Vaccination or More. J Homeop Ayurv Med 2012; 1:105. doi:10.4172/2167-1206.1000e105.

[118] Abdelrahman Mohamed Yehia TY, El-Ashry S, El-Batoty K, El-Hady S. Efficiency of Triple Antibiotic Mixture and Propolis as Intracanal Medication in Revascularization process in immature apex: A clinical study. Glob J Medical Clin Case Rep 2019;6(2):019-025. doi: http://doi.org/10.17352/2455-5282.000073.

[119] NIH. Clinical Alerts and Advisories /Disclaimer. U.S. National Library of Medicine, ClinicalTrials.gov. This page last reviewed in September 2017. https://www.nih.gov/coronavirus and https://www.coronavirus.gov. 
[120] Werner K, Werner K, Risko N, Burkholder T, Munge K, Wallis L, et al. Cost-effectiveness of emergency care interventions in low and middle-income countries: a systematic review. Bull World Health Organ2020; 98:341-352. Doi: http://dx.doi.org/10.2471/BLT.19.241158.

[121] Kaiser J. To streamline coronavirus vaccine and drug efforts, NIH and firms join. Science, ScienceMag.org. 17th April 2020.

[122] The Science Advisory Board Net. Bulk Antibody Production to Support COVID-19 Research \& More. Are You Involved in COVID-19 (SARS-CoV-2) Research? Let's Work Together. Letter Science Advisory Board.Net on Mon, 04 May2020b.<letters@scienceboard.net>

[123] News. Homeopathy in managing viral infections like COVID-19. BioSpectrum 10 April 2020.

[124] Sukul NC, Sukul A. High Dilution Effects: Physical and Biochemical Basis. Authors Nirmal C. Sukul, Anirban Sukul Copyright 2005 Publisher Springer Netherlands Copyright Holder, Springer Science \& Business Media B.V. eBook 2005; ISBN 978-1-4020-2156-5. doi: 10.1007/1-4020-2156-9, Hardcover ISBN 978-1-4020-21558 Softcover ISBN 978-90-481-6601-5 Edition Number 1Number of Pages XII, 130.

[125] Mahata CR. Avogadro Limit Washed out by Nano-Associates of Water which Continue as Information Carriers in Serial Dilutions and End up with Generalized Concept of Medicines. International Journal of Complementary \& Alternative Medicine 2017;9(4):00305. doi: 10.15406/ijcam.2017.09.00305.

[126] THE WEEK MAGAZINE, JOURNALISM WITH A HUMAN TOUCH. Scientists in Israel, Netherlands claim progress in COVID-19 antibody trials 'Such a neutralising antibody has potential to alter the course of infection'. Web Desk, May 06, 2020.

[127] E TIMES OF INDIA NEWS. Italy claims to develop first COVID-19 vaccine: Here is the current status of all the potential coronavirus vaccines. TIMESOFINDIA.COM, Health \& Fitness, Last updated on - May 6, 2020.

[128] Roy S. Locust attack: A joint fight by India and Pakistan, over the years. The Indian Express, New Delhi, Updated: May 29, 2020. 